\title{
Paving the Road for Mesenchymal Stem Cell-Derived Exosome Therapy in Bronchopulmonary Dysplasia and Pulmonary Hypertension
}

\author{
Vincent Yeung, Gareth R. Willis, Elizabeth Taglauer, \\ S. Alex Mitsialis, and Stella Kourembanas
}

\subsection{Introduction}

Infants born with extremely low birth weight (ELBW) have increased risk of developing a number of diseases including periventricular leukomalacia (PVL), retinopathy of prematurity (ROP), hypoxic-ischemic encephalopathy (HIE), bronchopulmonary dysplasia (BPD), and pulmonary hypertension (PH) [1]. With notable advancements in surfactant therapy, postnatal nutrition, the refining of steroid-based approaches and an ongoing improvement in ventilation strategies, the current standard of care for preterm infants not only supports their survival but also strives to minimize further organ injury and promote functional long-term recovery [2, 3]. Whereas recent studies established that the frequency of several morbidities associated with

V. Yeung · G. R. Willis · E. Taglauer · S. A. Mitsialis

S. Kourembanas $(\bowtie)$

Department of Pediatrics, Harvard Medical School, Boston, MA, USA

Division of Newborn Medicine, Department of Medicine, Boston Children's Hospital,

Boston, MA, USA

e-mail: vincent.yeung@childrens.harvard.edu;

Gareth.willis@childrens.harvard.edu;

Elizabeth.taglauer@childrens.harvard.edu;

Alex.mitsialis@childrens.harvard.edu;

Stella.Kourembanas@childrens.harvard.edu prematurity is decreasing [4], the prevalence of BPD is rising, perhaps as a consequence of our own successes and this persists in the era of lessinvasive mechanical ventilation [5].

BPD occurs almost exclusively in preterm infants that have required oxygen therapy and mechanical ventilation [6]. Although an accurate definition of BPD has historically lacked uniformity, it is characterized by delayed or disordered lung development, emphysema-like features of lung disease (alveolar simplification), decreased vascular surface area, and abnormal long-term pulmonary function $[7,8]$. Notably, secondary PH has been linked to moderate to severe cases of BPD and is characterized by remodeling of pulmonary arterioles, elevated pulmonary vascular resistance, right ventricular hypertrophy that may progress to failure and overall increased infant mortality [9, 10]. Arguably, current pharmacological interventions and past medical advances appear to have only a subtle impact on the severity and long-term consequences of the disease. Thus, there is an imperative need to expand our therapeutic arsenal by developing novel and safe interventions to effectively treat the primary damage and reduce the risks of further complications associated with extreme preterm birth [11]. Herein, we will highlight the application of cellbased therapies, focusing on mesenchymal stem cells (MSCs), and commenting on their immunomodulatory role in experimental models of 
neonatal lung injury and $\mathrm{PH}$, as well as the first clinical trials on MSC therapy on neonates. Furthermore, we will expand on the paracrine attributes of MSC therapeutic properties, presenting current progress towards the development of cell-free therapeutics based on MSC-derived exosomes/extracellular vesicles (MEx).

\subsection{Stem Cell-Based Therapies}

Stem cells have crucial roles in normal development and in maintaining homeostasis by aiding organ repair and regeneration throughout life, as they can undergo self-renewal and can differentiate into multiple cell types. They can be broadly divided into two categories: pluripotent stem cells (PSCs) and adult (somatic) stem cells, MSCs belonging to the latter category. The defining characteristic of these two stem cell types is that PSCs, either of embryonic origin (ESCs) or induced (iPSCs), can activate an extensive repertoire of differentiation pathways and are able to become almost all specialized cell types. Adult stem cells can only differentiate into a limited number of cell types closely related to their tissue of origin, or, in the case of MSCs, into cell types of mesenchymal origin. A property most relevant to the field of regenerative medicine is that PSCs have essentially unlimited renewing capability, and thus they can be readily expanded in tissue culture without losing their differentiation capabilities. That ability represents a major advantage over cultures of adult stem cells, which can be expanded for only limited passages and eventually lose their "stemness." The PSC advantage is also the basis of the great disadvantage in terms of live cell therapeutic treatments, as they have been associated with teratoma formation in vivo. For a recent concise review please see Kolios \& Moodley [12].

The immature organs of preterm infants are vulnerable to the detrimental effects of oxidative stress, infection, and associated insults resulting in tissue damage and perturbations of developmental pathways that, in the case of the immature lung, can lead to BPD and PH [6, 7]. It has been a valid assumption that depletion or dysregula- tion of endogenous stem/progenitor cell populations in the developing lung could arguably underlie tissue simplification and disease progression [13]. Therefore, an approach to restore homeostasis could be based on harnessing the well-established regenerative and immunomodulatory properties of stem cells. Indeed, over the past decade, a large number of studies, both in preclinical models of disease as well as in clinical trials, explored the promise of the therapeutic potential of interventions based on stem cell transplantation in a number of diverse diseases, albeit the original high expectations have yet to be fulfilled.

\subsubsection{Pluripotent Stem Cells (PSCs)}

PSCs are comprised of embryonic stem cells (ESCs) [14] and induced pluripotent stem cells (iPSCs) [15]. ESCs have extensive self-renewal capacity and can differentiate into specific germ layers. The identification of four key transcription factors (KLF4, OCT4, SOX2, and c-MYC) that can reprogram fully differentiated somatic cells into PSCs [16] has been a pivotal paradigm shift in the field. The potential to reprogram fully differentiated somatic cells is enormous, as the expansion could occur in vitro, but also, this could overcome immune-mediated rejection by providing as an autologous source of stem cells for transplantation.

There is a scarcity of studies addressing the potential of PSCs for in vivo lung repair. Notably, it has been reported that ESCs, differentiated into alveolar epithelial type II cells (ATII) can populate the mouse lung parenchyma upon endotracheal injection [17]. More recently, innovative approaches using in vitro differentiation regimens and reimplantation or organoid models have demonstrated the capacity of iPSCs to recapitulate the lung architecture and environment by generating distal alveolar epithelial cells and conducting airway epithelial cells $[18,19]$. Further, the airway delivery of human iPSCs-derived ATII to a hyperoxia-induced lung injury in vivo model improved lung function and structure [20], but the actual use of PSC transplantation in clinical trials on lung 
disease may be far in the future, as ethical constraints surround the generation of ESC lines and the pluripotent nature of both iPSCs and ESCs does raise grave concerns for potential teratogenic risks, as reviewed in [21-23]. In the lung field, the foreseeable current application for iPSCs will be in basic research, as they can be used to generate complex 3D lung organoids [24], useful in studies to understand lung development using in vitro tools. In the near future, iPSCs could be instrumental in whole organ tissue engineering to achieve the repopulation of decellularized xenogeneic lung matrix scaffolds with human cells. When proper topological distribution, cell-type differentiation, and long-term viability is achieved, these efforts could pave the road for unlimited availability of "humanized," transplantation-competent lungs in the not-too-distant future [25-27].

\subsubsection{Adult Stem Cells}

Originally, the best-described adult stem cells were hematopoietic stem cells, with their potential to reconstitute the entire hematopoiesis program of the bone marrow (BM). Since then, progress in stem cell biology has identified numerous stem/progenitor cells, including endothelial progenitor cells (EPCs), human amnion epithelial cells (hAECs), and MSCs. Transplantation of different adult stem cells types in preclinical models of neonatal disease, including neonatal brain injury [28], hypoxia-ischemia, and cerebral palsy [29], as well as stroke, BPD, and $\mathrm{PH}[13,30,31]$, have produced very promising results.

EPCs were first identified and isolated from adult peripheral human blood [32], and shown to retain the capacity to differentiate into functional endothelial cells and sustain vasculogenesis. It was hypothesized that EPCs administration would benefit infants at risk with BPD. Indeed, administration of conditioned media (CM) derived from endothelial colony-forming cells (ECFCs) promoted angiogenesis in vitro and ameliorated parameters of $\mathrm{PH}$ subsequent to experimental BPD [33]. Intravenous (IV) infusion of human umbilical cord blood (UCB)- derived ECFCs into immuno-deficient rodents exposed to hyperoxia promoted lung vascular growth and attenuated alveolar injury [34]. A disconcerting observation in these rodent animal models was the appearance of aberrant tissue growth in the lungs upon transplantation of longterm cultured EPC-like lines [35]. Although such growth was not observed using fresh EPC cultures, safety concerns may be raised in using such cells in human clinical trials. In contrast, hAECs may represent a promising perinatal tissue-derived product for BPD treatment, as they exhibit mostly anti-inflammatory properties and are isolated from the amniotic membrane at birth [36]. Studies have highlighted that hAECs attenuate the fetal pulmonary inflammatory response and promote the lung-protective effects in neonatal mouse and sheep models [37, 38]. Administration of hAECs in neonatal models of BPD by IV or intratracheal (IT) routes effectively ameliorated alveolar injury and reduced fibrosis with some evidence of transdifferentiation events and cell engraftment [39]. As it has been firmly established for MSCs (see below), it has been suggested that the main mechanism of protection by hAECs against acute and longer-term injury is predominantly paracrine [40, 41]. The donor cells exert their beneficial effects by modulating the local inflammatory response, rather than through tissue repair and engraftment in the recipient lung, as had been postulated in earlier studies [37, 39].

\subsection{Mesenchymal Stem Cell- Based Therapies in Preclinical Models of Lung Injury}

Mesenchymal stem cells were originally isolated from the bone marrow [42], and subsequently from several other adult tissues such as adipose [43], dental pulp [44], and Wharton's jelly [45]. Early work stressed the multipotent attributes of MSCs, as witnessed by their ability to differentiate into mesoderm-derived lineages. The International Society for Cellular Therapy (ISCT) proposed minimal requirements to define human 
MSCs, which entail: (1) adhesion to plastic; (2) expression of the cell surface markers CD73, CD90, and CD105; and (3) lack of CD11b or CD14, CD34, CD45, CD19 or CD79 $\alpha$, and HLA-DR surface expression; (4) ability to differentiate into adipocytes, chondrocytes, and osteoblasts in vitro [46]. The exact definition of MSCs is still evolving, as methodologies used in isolating, expanding, and characterizing MSCs differ considerably between research groups. It has been realized that MSC isolates can exhibit significant inter-culture and intra-culture variation both in surface markers and differentiation potential $[47,48]$. It is therefore important to carefully consider the source, lineage, and age of MSC cultures to be used for studies involving therapeutic applications and be aware of possible significant variations in their transcriptome and proteome [43, 49-51]. Indeed, development of novel screening technologies is critical to fully characterize large panels of surface markers and the MSC populations they represent [52, 53]. Driven by these considerations the current consensus is that mesenchymal stromal (rather than stem) cells should be the more appropriate designation for MSCs, a moniker that reflects observed heterogeneities in functional properties and differentiation potential.

The ease of isolation, expansion, and in vitro differentiation potential of MSCs made them a favorite reagent in preventive and regenerative studies on a wide spectrum of animal models of disease, and MSC transplantation was shown to be very effective in ameliorating and even reversing critical parameters associated with lung diseases, as reviewed in [54-59]. In order to model interstitial lung diseases, bleomycin-induced lung injury is commonly used, inducing pulmonary fibrosis as well as pulmonary hypertension through proinflammatory and fibrotic reactions. The mouse bleomycin model allows for mechanistic studies in these two pathological processes that also exist in BPD-fibrosis to a milder degree and $\mathrm{PH}$ seen in moderate to severe cases of BPD [9]. Early studies using the bleomycin mouse model of pulmonary fibrosis [21, 60-63] reviewed in [64] demonstrated that MSC treatment was very effective if administered during the initial phase of inflammation, improving collagen deposition and the Ashcroft score for fibrosis. Animal survival was also improved, and inflammatory markers were reduced in the bronchopulmonary lavage. Nevertheless, MSC treatment was less effective in reversing the fibrotic phase of the disease. Similarly, studies on a rat monocrotaline (MCT) model of pulmonary arterial hypertension demonstrated that either IV or IT administration of BM-derived endothelial progenitors [65] or BM-derived MSCs [66-69] ameliorated arteriolar narrowing, alveolar septum thickening and right ventricular hypertrophy (RVH), and improved RV function and pulmonary vascular resistance, whilst improving endothelium-dependent responses.

Using the mouse model of hypoxia-induced pulmonary hypertension (HPH), Liang et al. demonstrated that the therapeutic effect of mouse BM-MSC treatment was associated with the suppression of the lung inflammatory response induced in the early stages of hypoxic exposure [70]. In this work, a careful assessment of a number of male donor MSCs residing in the recipient female lung demonstrated that the dramatic physiologic effect was associated with insignificant donor cell engraftment. In studies on the hyperoxia-induced neonatal rodent model of BPD, BM-MSC treatment, either by the IV or IT routes, was shown to be effective in protecting against arrested lung vascular and alveolar development [71, 72]. Significantly, and congruently with the low donor cell engraftment observed in the HPH studies, media conditioned by MSCs conferred a similar, or even more robust, protective effect in vivo [71], buttressing the concept that MSC therapeutic action in the lung is predominately paracrine (see below). Subsequent confirmatory studies showed that MSCs isolated from human umbilical cord blood (UCB) can be effective in attenuating hyperoxia-induced lung injury in neonatal rats, exerting both short-term and long-term (6 months) therapeutic benefits, with persistent improvement in exercise capacity and lung structure and without adverse lung effects [73, 74]. Significantly, in the hyperoxiainduced BPD model, UCB-derived MSCs showed significant protection only in the early, 
but not the late phase of lung inflammation [73]. This parallels the studies demonstrating that suppression of the early inflammatory peak induced by hypoxia in the mouse model of HPH, by either BM-MSCs [70] or ectopic expression of the cytoprotective enzyme Hmox1 [75], confers longterm protective benefits. This strongly suggests that MSC treatment for lung disease may prove to be more efficacious in preventing the establishment of pathology, arguably by restoring homeostasis at the onset of injury, rather than reversing established injury.

\subsubsection{The Therapeutic Action of MSCs in the Lung Is Predominantly Through Paracrine Mechanisms}

The original promise of MSCs was that their plasticity and multipotent differentiation capacity would permit the development of therapies where the donor cells would participate in extensive repair and regeneration of injured or diseased lung tissue. Indeed, some early reports, fueled by enthusiasm for the new regenerative paradigm, claimed wide-spread engraftment of donor MSCs into the recipient lung, and massive in situ differentiation of donor cells into pneumocytes residing in the recipient lung [60, 61, 76-78]. Subsequent studies, however, clarified that the impressive improvement in lung physiology observed by MSC transplantation therapy could not be accounted for by donor cell engraftment and trans-differentiation as originally reported. Indeed, careful studies transplanting male mouse BM-MSCs in hypoxic females revealed that donor MSCs survive only a few days in the lung, and although engraftment and transdifferentiation into pneumocytes, in particular alveolar type II epithelium, was observable, the actual number of engrafted donor cells was miniscule [70]. In parallel studies, using a hyperoxia-induced neonatal mouse model of BPD, Aslam et al. reported that media conditioned by mouse BM-MSC (MSC-CM) were more beneficial than IV injections of MSCs in reducing fibrosis and improving alveolar simplification [71]. In a follow-up study, when neonatal mice were exposed to hyperoxia $\left(75 \% \mathrm{O}_{2}\right)$ for 2 weeks to initiate lung injury, it was demonstrated that a single dose of mouse MSC-CM reversed the hyperoxia-induced parenchymal fibrosis and peripheral devascularization (pruning), ameliorated $\mathrm{PH}$ and $\mathrm{RVH}$, improved lung alveolar development, and normalized lung function (dynamic lung compliance and airway resistance) [79].

The realization that paracrine factors play a major, if not the sole role in the mechanism of MSC therapeutic action [79-81] has by now been confirmed by many independent studies [82-84]. More recently, a meta-analysis evaluated the therapeutic potential of utilizing MSCs and MSC-CM in experimental BPD [85]. This analysis of 25 controlled studies that met the inclusion criteria used lung alveolarization as the primary outcome and the authors reported that specifically, the administration of MSC-CM significantly improved alveolarization, ameliorated lung inflammation and fibrosis, without comprising safety and efficacy.

Results from these preclinical models strongly suggested that the beneficial effects of MSC paracrine activity are associated with modulation of the host immune system, congruent with the known attribute of MSCs as potent immunomodulators [86-88]. Nevertheless, the exact molecular mechanism(s) remain under active investigation and certain hypotheses have been advanced on the nature of the MSC immunomodulatory paracrine activity and on the host target cell(s) that respond to these MSC signals. Initial efforts in identifying the active therapeutic moieties in the MSC secretome had predominantly focused on growth factors, chemokines and cytokines [89-91], but it became evident that not one single molecule could possibly account for all the observed diverse effects, and not one single molecule could recapitulate all the therapeutic function when administered in isolation. As discussed below, it was soon realized that the vector of MSC therapeutic function was represented by a higher order of complexity, to wit MSC-derived extracellular vesicles. 


\subsection{Extracellular Vesicles: The Therapeutic Vector of the MSC Secretome}

Extracellular vesicles (EVs) are a heterogeneous class of lipid bilayer-enclosed microparticles, harboring diverse plasma membrane and cytoplasmic components. Such submicron structures are produced by all cells (including prokaryotes), and they were originally characterized as a mechanism through which the cell may jettison unwanted molecules, akin to a cellular "garbage shuttle." Although components of the mechanism have been coopted in evolution to also serve other purposes, notably the generation of retroviral particles, the great majority of EVs produced by a normal, healthy cell is, arguably, garbage. Nevertheless, it appears that certain cell types may have evolved a mechanism to produce a subclass of EVs designed for broadcasting signals to their environment, to sustain surveillance of, and, in turn, to affect other cells. That active EV subpopulation, which we can term the "signalosomes," plays a significant role in health and disease, and this realization has opened new research themes for future EV therapeutic application across multiple disciplines. We will discuss here basic tenets of EV biology and the recent and exciting realization that MEx represent the therapeutic vector of the MSC secretome.

\subsubsection{EV Diversity and Nomenclature}

The size and molecular characteristics of EVs are diverse, and full definition of EV subclasses and their biogenesis remains an active field of research [92]. As described in more detail in Chap. 4, EVs can generally be divided into three main types: (1) exosomes, defined as vesicles of approximately 30-150 $\mathrm{nm}$ in diameter and of endosomal origin, appear as intraluminal vesicles (ILVs) in multivesicular bodies (MVBs) and they are released as EVs upon fusion of the MVB with the plasma membrane; (2) microvesicles (MVs), defined as vesicles of approximately 150 $1000 \mathrm{~nm}$ in diameter that bud directly from the plasma membrane; (3) apoptotic bodies or blebs (ABs), defined as vesicles greater than $1 \mu \mathrm{m}$ in diameter and released from cells undergoing apoptosis [93]. Of these three major classes, the exosomes are the products of a most intricately controlled biogenesis pathway, with a finely tuned selection of cargo. It is therefore safe to hypothesize that the signalosomes, the putative therapeutic vector of MSCs, represent an exosomal subclass [94]. The International Society of Extracellular Vesicles (ISEV) has defined minimal framework guidelines to characterize EVs and their function [94-96]. The term "EVs" is suggested to denote all extracellular vesicles where the purity of a particular preparation cannot be ascertained and ISEV requirements include biophysical properties, subcellular origin, and protein markers, useful as standards to identify the heterogeneous nature of EVs. This incomplete understanding of $\mathrm{EV}$ diversity is mostly due to technological limitations in efficiently separating EV subpopulations based upon their molecular profile. Novel approaches, separating EVs based upon biophysical properties, such as asymmetric flow field-flow fractionation (AF4) are expected to facilitate EV subclass definitions [97], and, when applied to MEx preparations, will permit the enrichment of a more homogeneous signalosome population that will further our understanding of the relevant cargo conferring the action of MEx on recipient cells.

\subsubsection{Exosome Biogenesis and Secretion}

The formation of MVBs consists of highly dynamic endosomal membrane compartments involved in the internalization of extracellular protein, ligands, or cellular components, their recycling to the plasma membrane, and/or their degradation [98]. Early endosomes mature into late endosomes and are denoted as MVBs due to their morphological features. During this process, they accrue ILVs in their lumen, through invagination of the defining lipid bilayer, and ILVs are considered to be the precursors to the "true exosomes" (Fig. 8.1). ILVs are formed by 


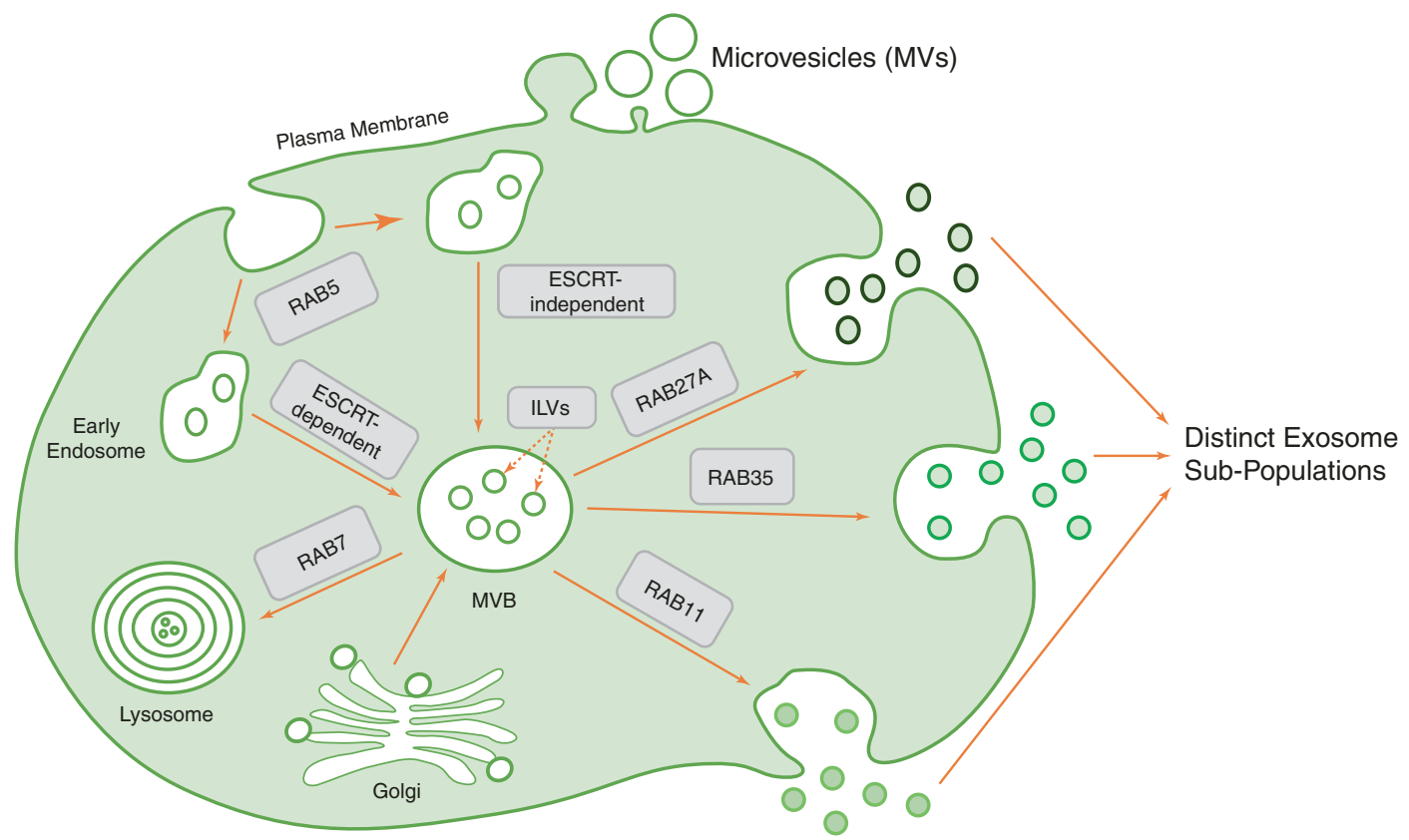

Fig. 8.1 Schematic representation of EVs from different intracellular origin and the molecular machineries of exosome/EV biogenesis and secretion. Microvesicles (MVs) can be released from direct budding from the plasma membrane. Multiple machineries are involved in the biogenesis of intraluminal vesicles of multivesicular bodies (MVB) via endosomal sorting complex required for transport (ESCRT)dependent or independent mechanisms. It remains unknown

inward budding of the early endosomal membrane, sequestering proteins and lipids that are specifically sorted. The formation of MVBs and ILVs are processed by the endosomal sorting complex required for transport (ESCRT) complex, containing approximately thirty proteins. This has four distinct ESCRT complexes (ESCRT-0, -I, -II, and -III), with associated proteins such as programmed cell death 6-interacting protein (ALIX), vacuolar protein sortingassociated protein 4 (VPS4), and vacuolar protein sorting-associated protein (VTA1). These complexes and proteins have distinct tasks including: interaction with ubiquitinated membrane proteins to membrane deformation and abscission [99]. Upon MVB maturation, trafficking of MVBs between organelles and the extracellular space is governed by small Ras-associated (RAB) GTPase proteins that are essential for regulating transport between different endosomal whether they act simultaneously on the same MVB or on different MVBs. The Ras-protein (RAB) family has roles in modulating endosomal trafficking; with RAB7 trafficking MVBs for lysosomal degradation; RAB11, RAB27A, and RAB35 have been shown to promote exosome secretion by trafficking MVBs to the plasma membrane. It is proposed that secretion of Distinct Exosome Sub-Populations is governed by the RAB protein family as reported [124, 147, 148]

compartments [100]. The RAB GTPase superfamily, composed of at least 60 proteins, can play vital roles in controlling membrane identification and MVB budding, motility, uncoating, and fusion [101]. The final step of exosome release, involves fusion with the acceptor membrane that depends on the protein family, soluble $\mathrm{N}$-ethylmaleimide-sensitive fusion attachment protein receptor (SNARE) [102]. Members of this family are categorized as vesicular SNAREs (v-SNARE) located on the vesicle's membrane and target SNAREs (t-SNARE) located on the membrane of acceptor compartments [103, 104]. This process is proposed to allow the SNARE proteins to form complexes between the MVB and plasma membrane to mediate fusion; thus, allowing the release of ILVs, termed as exosomes, often represented by a heterogeneous population that differs in their molecular composition. 


\subsubsection{Composition of Extracellular Vesicles}

The molecular composition of EVs remains variable and dependent upon the cellular origin, stimuli, and their biogenesis. During biogenesis, EVs incorporate an array of bioactive cargo from their parent cells. Some of the cargo can be reported to include genetic information in the form of DNA, mRNA, noncoding RNAs (microRNA: miRNA), free fatty acids, and proteins. Extracellular vesicle characterization has been aided by the development of comprehensive databases such as ExoCarta [105], Vesiclepedia [106], EVpedia [107], and exoRBase [108] that assembled EV findings from different studies with the goal of aiding investigators in finding molecular signatures specific to cell/tissue type. As a result, certain proteins were identified as being exosome-associated, including flotillin-1 (FLOT1), ESCRT-related proteins, ALIX and tumor susceptibility gene 101 (TSG101), the tet- raspanins, CD9, CD63, and CD81, RABs, SNAREs, and others (Fig. 8.2). EV membranes are also enriched in cholesterol, sphingomyelin, ceramide, and lipid raft proteins [95, 109]. Furthermore, EVs express integrins which may contribute to delivering their bioactive cargo to specific tissues and organs [110], but the cargo's fate remains unclear and appears dependent on the route of uptake (caveolin, clathrin, pinocytosis, micropinocytosis, and others) [111]. The bioactive cargo can reflect the stimulus that triggered EV formation, suggesting the packaging of a "signal" can be exported from the parent cell; thus, EVs may act instrumentally for cell-cell communication [112-116]. The specific mechanism(s) by which EVs deliver their cargo and elicit functional responses with target cells remains poorly understood, but EV-target cell interaction is likely to be cell- and EV specific. Some different uptake/endocytic-related pathways may be involved to direct membrane fusion, depending on the cell type.

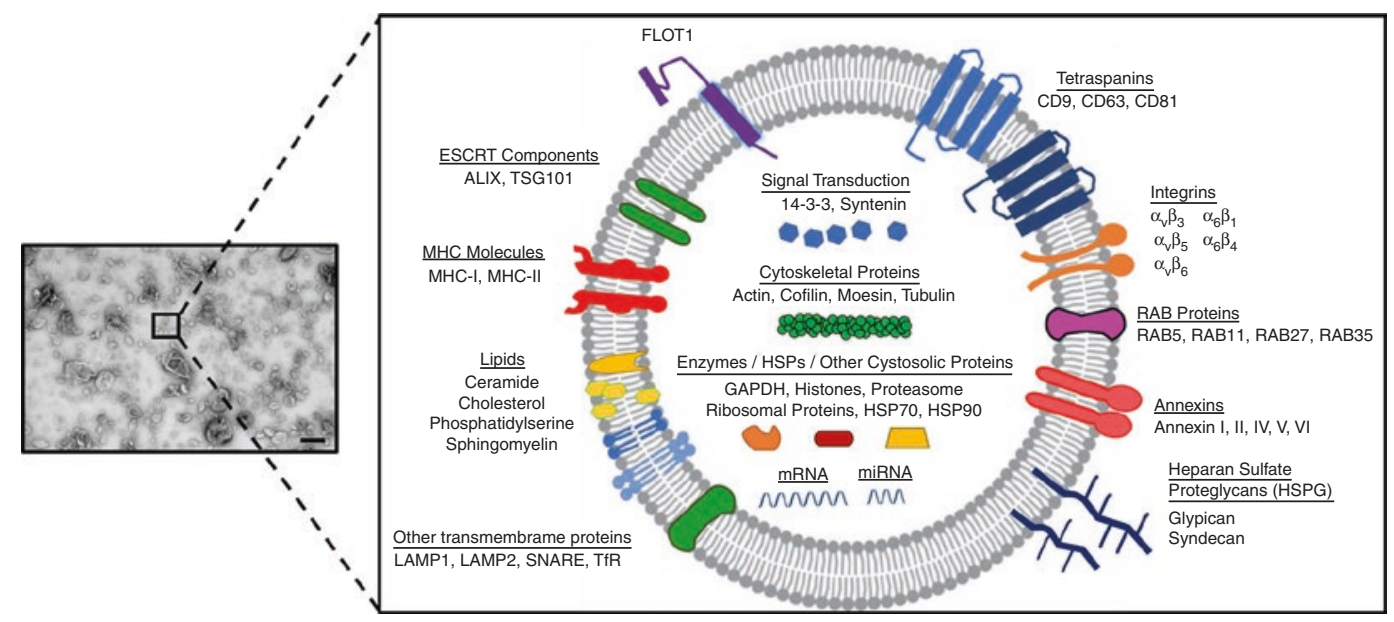

Fig. 8.2 Mesenchymal stem cell exosomes (MEx). Left panel: Transmission electron microscopy of MEx derived from human umbilical cord Wharton's Jelly. Exosomes are heterogeneous by nature but typically contain a diameter between 30 and $150 \mathrm{~nm}$. Scale bar: $200 \mathrm{~nm}$. Right panel: Typical structure and molecular composition of exosomes. Exosomes are surrounded by a phospholipid bilayer, enriched in several lipids such as ceramide, cholesterol, phosphatidylserine, sphingomyelin. They contain proteins such as flotilin-1 (FLOT1), programmed cell death 6-interacting protein (ALIX), tumor susceptibility gene 101 (TSG101), major histocompatibility complex-I and -II (MHC-I and -II), lysosomal associated membrane protein-1 and -2 (LAMP-1 and -2), transferrin receptor (TfR), tetraspanins, integrins, small GTPase Ras-related (RAB) proteins, annexins, and heparan sulfate proteoglycans (HSPGs). Exosomes can also contain signal transduction molecules, cytoskeletal proteins, enzymes, heat shock proteins (HSPs) and can contain RNA or small noncoding RNAs. The exosomal cargo serves to mediate intracellular communication between different cell types within the body, thus functioning differently in either normal homeostasis or pathological conditions. GAPDH: Glyceraldehyde 3-phosphate dehydrogenase; ESCRT: Endosomal sorting complex required for transport; SNARE: soluble $N$-ethylmaleimide-sensitive fusion attachment protein receptor 
The wide repertoire of miRNAs in MEx could conceivably provide a miRNA-based mechanism for therapeutic function of MSC secretion. It was first reported that RNA was transferred from mouse mast cells to human mast cells via exosomes [117] and this was similarly described in Epstein-Barr virus-infected cells [118] and COS-7 cells [119]. One report found that miRNAs in MSC-derived EVs, more specifically miR125b-5p (known to target p53) levels were increased in neonatal mouse cardiomyocytes, when cultured with MEx [120], suggesting exosomal transfer of miRNA. By using an anti-miR$125 \mathrm{~b}-5 \mathrm{p}$ oligonucleotide, the authors demonstrated MSC-derived EVs effects, may be entirely dependent on miRNA transfer and this was supported in similar studies [121, 122]. Although, the mechanism of action still needs to be addressed, with the broad application of MSC-derived EVs or MExbased therapeutic application, a single mechanism may not be definitive to address all related diseases. A collective effort remains in elucidating the mechanism(s) of action of EV function and the specific biological moiety responsible for their functional output. With the heterogeneous population of EVs, studies have demonstrated a range of effects in vitro and in vivo disease models, based on density [123], protein [124] or size [97] of EVs. It still represents a prominent challenge in unravelling the complexity behind EV biogenesis and secretion, as identifying the vital bioactive moieties responsible for their biological effect remains unknown. We understand that different EV subpopulations harbor diverse protein and transcriptional cargo; it is fair to speculate they are likely to mediate different effects on target cells. Thus, improved separation techniques between the "nonactive" and enrichment of the "bioactive" EV subpopulation will allow us to understand the key mechanistic function potentially utilized in neonatal disease models such as BPD and PH.

\subsection{MEx-Based Therapies for Lung Disease}

As already discussed, the current dogma is that MSCs act predominately via paracrine mechanisms to confer protection in animal models of lung disease [71, 79], and that the main vector of this paracrine mechanism is comprised by MSCEVs (MEx) [125, 126] as reviewed in [30, 127129]. The first report, to our knowledge, that EV preparations isolated from MSC-CM albeit not extensively purified or thoroughly characterized, could substitute for MSC treatment in vivo, was that of Bruno et al., who used an acute kidney injury animal model [130]. Subsequently, Lai et al. reported that EVs secreted by human MSC cultures mediated the cardioprotective effects of MSCs in a myocardial ischemia/reperfusion injury model [131]. The report of Lee et al. [125] was the first demonstration that MEx treatment represented a therapeutic alternative for lung pathologies. Using a mouse model of $\mathrm{HPH}$, we reported that mouse BM-MSC MEx, isolated and characterized as per ISEV requirements and further purified through size exclusion chromatography, could protect the animals against the development of lung vascular remodeling, elevated artery pressures, and RVH after 3 weeks of hypoxic exposure at $8.5 \% \mathrm{O}_{2}$. A single dose of MEx suppressed the early hypoxic inflammatory response, characterized by the pulmonary influx of macrophages, attenuated the levels of hypoxiainduced inflammatory cytokines in the lung and protected against the development of vascular remodeling and pulmonary hypertension. Significantly, EVs produced by fibroblasts were inactive, and MSC-CM depleted of exosomes by size exclusion chromatography had no effect, demonstrating that the therapeutic activity was clearly associated with the vesicular fraction of the MSC secretome. Extending these studies to the hyperoxia-induced BPD model, we demonstrated that treatment with MEx derived from human MSCs was effective in radically improving lung morphology and pulmonary development, decreasing lung fibrosis, rescuing pulmonary vasculature loss, and ameliorating vascular remodeling in the mouse lung [126]. Significantly, EVs produced by either human BM MSCs or Wharton's Jelly MSCs were shown to be equally efficacious. This observation should facilitate future large-scale production of MEx, as umbilical cords represent a more abundant source of MSCs than bone marrow, and no invasive procedures are involved in collecting this material. 
Arguably even more important is the fact that the young MSC cultures from the cord stroma are pristine, as they do not carry the mutational or epigenetic imprints of the adult donor's health record. This should generate greater reproducibility in MSC clone characteristics, and more uniformity in MEx preparations. Interestingly, the drastic effects we have observed in the murine models of lung disease have been achieved by a single bolus of MEx delivered IV. This strongly suggests that MEx treatment may result in a reprogramming of the recipient's immune system, bestowing longterm protection, despite the continuous environmental insult (hyperoxia or hypoxia) [129]. The hypothesis had originally been advanced that modulation of lung macrophage polarization may represent a protective mechanism against lung injury [75]. Indeed, the immunomodulatory action of MEx on lung macrophages was readily evidenced by assessing the expression of markers associated with either the "M1-like" (classical; proinflammatory) or the "M2-like" (alternate; nonclassical) states of polarization [126]. It is important to realize that macrophage polarization represents a continuous spectrum, and the simple $\mathrm{M} 1 / \mathrm{M} 2$ dipolar classification is no longer able to describe the diverse phenotypes. Therefore, the detailed definition of the protective state into which lung macrophages are reprogrammed by MEx treatment is currently an active area of study.

Subsequent studies in the field confirmed and expanded the above original reports, and the bulk of the more recent reports have established the effectiveness of rodent MEx, but also, most significantly, of MEx of human origin in diverse preclinical models of lung disease. Notably, MEx of human origin, systemically delivered, were shown to be even more effective than mouse MEx in mitigating Th2/Th17-mediated allergic airway inflammation in a mouse of asthma induced by Aspergillus hyphal extract [132]. This model is of relevance to neonatal lung pathologies, since there is high prevalence of reactive airway disease at 8 years of age in former preterm infants with BPD [5]. In the rat model of monocrotaline (MCT)-induced PH, MEx isolated from rat BM were reduced right ventricular hypertrophy (RVH) and pulmonary remodeling [133]. In the same model, MEx-containing EV preparations pre- vented parameters of $\mathrm{PH}$ when given at the time of MCT administration and ameliorated these pathologic features when given after the establishment of disease [134]. The mechanism of therapeutic/protective action of MEx treatment for lung pathologies is based on immunomodulation, and more specifically on reprogramming the macrophage phenotype [30, 129]. Studies in the BPD model, using MEx derived from preterm cords, also suggested the importance of TSG-6 protein (TNF alpha-induced protein 6; product of the TNFAIP6 gene) as a MEx cargo component crucial for their therapeutic action [135], but the mechanistic details at the molecular level remain to be defined. The IT route of administering MEx was reported to be effective in a rat model of BPD, where both MEx and MSCs were shown to be effective against hyperoxia-induced damage, but MEx were observed to be more efficacious in terms of alveolarization and lung vascularization parameters [136]. The aggregate promising results on MSC-based and MEx-based therapies on preclinical models of lung disease have therefore created the stage for the first clinical trials.

\subsection{MSC-Based Clinical Trials on Neonates}

Ongoing clinical trials using MSCs to treat lung diseases, most notably Acute Respiratory Distress Syndrome (ARDS), Chronic Obstructive Pulmonary Disease (COPD), and Idiopathic Pulmonary Fibrosis (IPF) have established the safety (at least in the short- and intermediate term) of MSC treatment and have yielded invaluable information for crafting the strategies necessary to translate procedures from bench to bedside and improve the efficiency of live cell MSC-based therapies [137-140]. Analyzing the lessons from these pilot studies is beyond the scope of this discussion, and herein we will focus on reviewing ongoing clinical trials of MSC treatment for BPD and highlighting the considerations for MSCbased or MEx-based treatment of the neonate.

In 2014, the first Phase I clinical trial of MSCcell therapy for BPD prevention was reported [141]. Using a single-arm, dose-escalation design, the study involved 9 preterm infants born at 
$25.3 \pm 0.9$ weeks gestational age. These patients had a mean birthweight of $793 \pm 127 \mathrm{~g}$, with no known severe congenital anomalies and no clinical evidence of septic shock or severe ( $\geqq$ Grade 3 ) intraventricular hemorrhage at the time of the study. At a postnatal age ranging from 5 to 14 days, the patients were determined at the "highest risk" for BPD based on the clinical criteria of continuous ventilatory support and an inability to tolerate weaning of ventilatory support in the $24 \mathrm{~h}$ prior to recruitment. The 9 recruited infants were administered a single, IT dose of the allogenic human UCB-MSCs at an average timeframe of $10.4 \pm 2.6$ postnatal days. The first three patients were administered a dose of $1 \times 10^{6}$ cells (low dose). With no onset of short-term adverse events noted in these series of patients, the subsequent 6 patients were administered $2 \times 10^{6}$ cells IT (high dose). The infants were closely monitored for signs of cardiorespiratory compromise, anaphylaxis, infection and other serious adverse events (SAE) as defined by the Consolidated Standards of Reporting Trials [142]. The reportable SAE within the cohort included patent ductus arteriosus (PDA) ligations (4/9 patients). Apart from these events, IT administration of MSCs appears well tolerated within these patients with no significant clinical compromise noted in the short-term period.

Levels of lung inflammatory markers were investigated in the tracheal aspirates that included IL-6, IL-8, and TNF- $\alpha$ which have roles that may augment an inflammatory cascade and exacerbate lung injury by mediating macrophage "classical" activation, neutrophil infiltration, and maintaining proinflammatory cytokine expression inhibiting lung development. A reduction in these markers was observed at 7 days post transplantation compared to pretransplant levels. However, lacking a parallel control group during the study invites further questioning, as it remains unclear whether this change was related to the natural infant's lung disease progression or MSC administration. However, due to the timeframe of this study (up to 36 weeks corrected gestational age), 3/9 patients went on to develop moderate BPD and no formal conclusions can be made regarding the clinical efficacy of MSCs in treating BPD.

This study demonstrated the feasibility and short-term safety of IT administration of MSCs, laying the groundwork for future clinical trials. In their follow-up study, patients were continued to be monitored at regular intervals for 2 years following MSC administration and reported the clinical outcomes of this longer-term evaluation [143]. From the 9 patients that received IT MSC therapy, 8 survived long term, with 1 patient's death occurring due to Enterobacter cloacae sepsis/enteritis following discharge from the NICU. The 8 surviving infants were rehospitalized an average of 1.4 times during the 2-year post-NICU-discharge evaluation period, with approximately $50 \%$ of these admissions due to respiratory viral infections (rhinovirus, parainfluenza, and RSV). Furthermore, the infants did not show any signs/symptoms of teratoma formation during this follow-up period, and no visible mass lesions were detected on chest radiographs taken on their third interval visit. This was an important follow-up parameter to consider as administration of some stem cells (PSCs or ESCs) into immunocompromised, premature patients carries a potential risk for teratoma formation. Therefore, MSC administration based upon the follow-up study appears to be safe with no SAE occurring in the neonatal population.

A similarly designed Phase I trial was reported on 12 ELBW infants that demonstrated feasibility and tolerance of MSC administration [144]. Further conclusions regarding efficacy of MSC therapy in the neonatal population will require larger patient cohorts with the concomitant evaluation of appropriate control populations. With accumulating preclinical evidence on MSC's ability to also reverse BPD-associated $\mathrm{PH}$, future MSC clinical trials for BPD should continue concomitant evaluation of cardiac function, in both short-term and long-term outcome evaluations. In the Phase I BPD MSC study [141], serial echocardiograms were performed pre and post MSC therapy showing no alteration in cardiac function and specifically no $\mathrm{PH}$. However, a larger proportion of the neonatal "at-risk" BPD population with more long-term evaluations of cardiac function will be significantly valuable in determining the potential of MSC therapy in prevention of BPD-associated PH. The pertinent clinical data from these studies and current active trials are summarized in Table 8.1. 

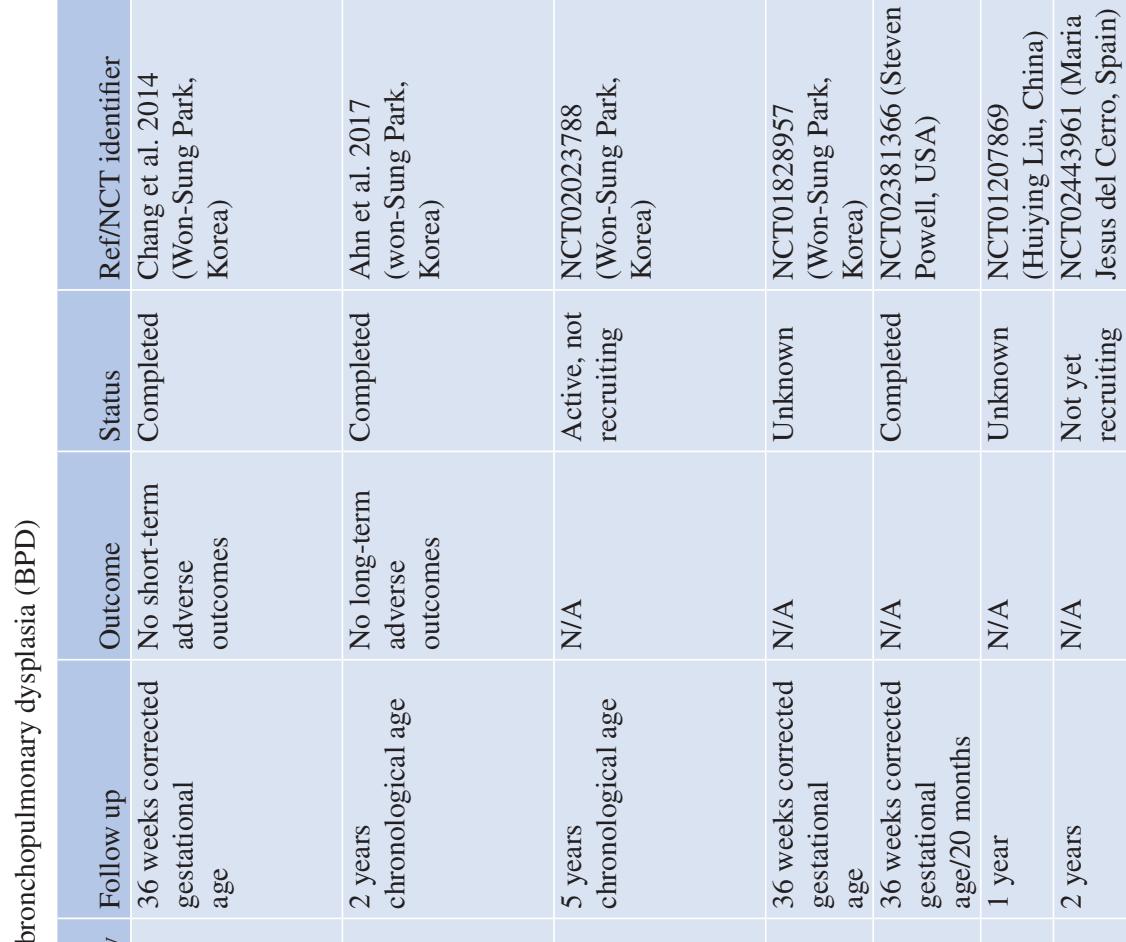

¿্<smiles>C1CC[Te]C1</smiles>
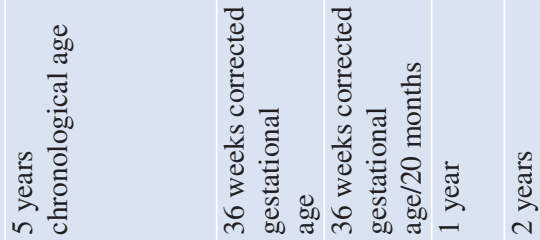

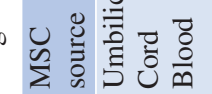
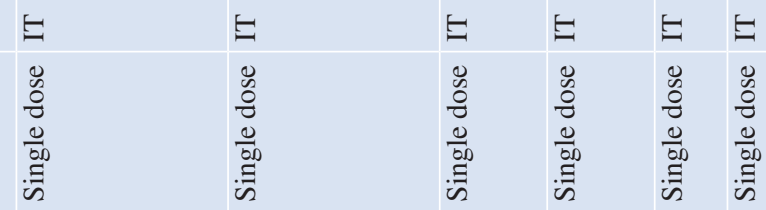

్ㅣㄹ

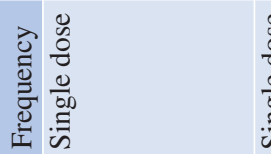

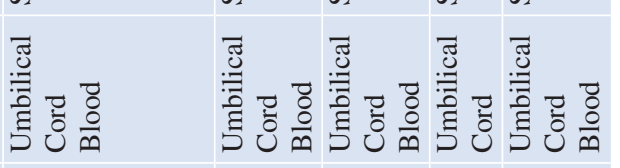

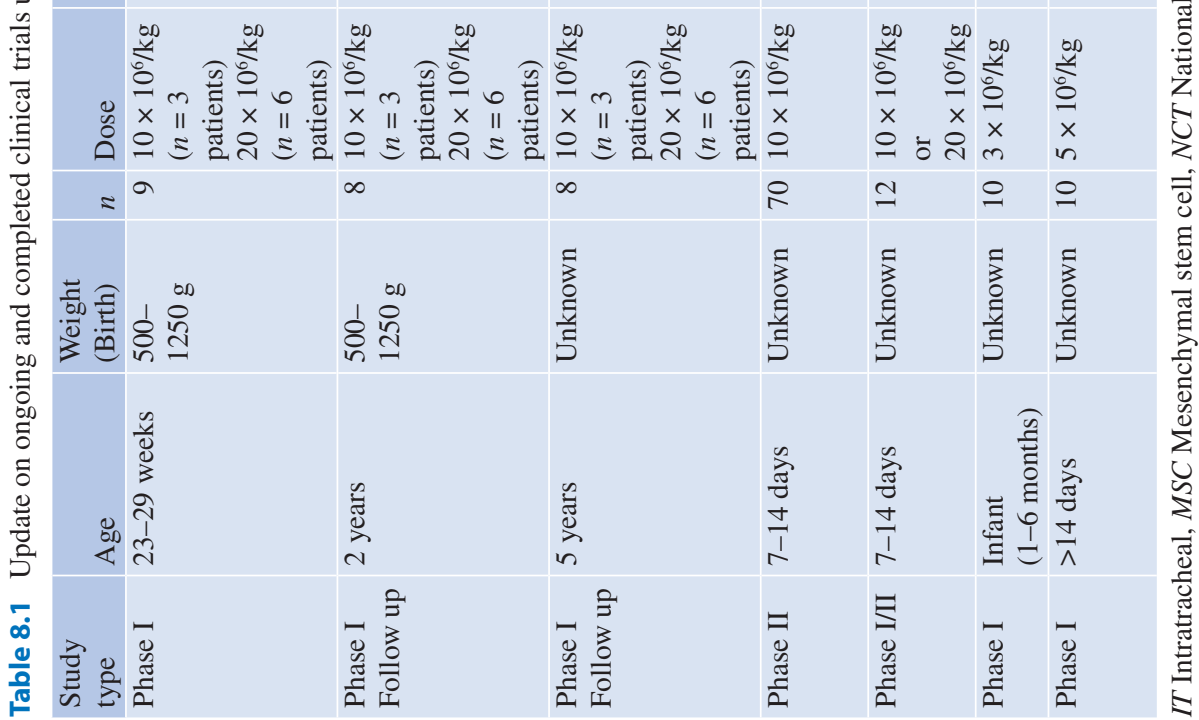


Interestingly, the safety profile of stem cellbased therapy for infant cardiac disease has been explored for several years prior to the initiation MSC cell-based therapy for BPD [145]. However, the clinical trials to date have primarily focused on autologous cardiac progenitors or EPCs administered to infants with hypoplastic left heart syndrome or idiopathic PH. Overall, this demonstrates safety profiles for stem cell transplantation for neonatal/infant cardiovascular conditions with some potential promising outcomes for improvement particularly in right ventricular function. While cardiac progenitor cells may align with the physiologic needs of congenital cardiac disease, the $\mathrm{PH}$ associated with BPD is multifactorial in origin and will likely benefit from the broader therapeutic capabilities of MSC-based therapies.

\subsection{Considerations and Challenges for MSC- Based Therapies in the NICU}

The initial results from MSC-based clinical trials for BPD are highly promising. While BPD is treated as a "multisystemic" disease given its established causal relationship with $\mathrm{PH}$, the preand postnatal events leading to BPD development (such as growth restriction, premature birth, hyperoxia) are also implicated in other organ pathologies in the multisystemic syndrome of prematurity. For example, apart from $\mathrm{PH}$, retinopathy of prematurity (ROP) and intraventricular hemorrhage are among the highest comorbidities associated with severe BPD phenotypes. While these diseases can be attributed to separate organ-specific pathologies, they are combined under the concept of a developing preterm infant fetus that is having to further develop in an "extrauterine" environment. This environment may provide basic life-sustaining support, but still lacks the benefit of a healthy gestational molecular network within the developing womb. This is a potential reason why Wharton's Jelly MSCs should be considered as a "first-line" treatment modality for neonatal disease such as BPD. These MSCs growing in the intrauterine environment exist within and likely contribute to the same "homeostatic" complex network of molecular signals as the developing infant [51]. In this context the promising reports from the ongoing clinical trials give us hope that future refinement of methodology and careful selection of the MSC cultures will lead to high therapeutic efficacy and reproducible outcomes. It is safe to assume that, if in the future live cell-based therapy for the neonate becomes commonplace, MSCs from the umbilical cord will be used. They have been demonstrated to be as efficacious as BM-derived MSCs in preclinical models, and they represent a young, pristine cell type, that does not carry the possible burden of a lifetime history to pathogens and environmental insults that adult BM MSCs have been exposed to.

Based on the positive therapeutic findings from preclinical studies from a range of different diseases [114], there is good reason to be highly optimistic for the outcomes of clinical trials on MEx-based therapeutics for BPD. The advantages of a reagent that encapsulates the therapeutic action of MSCs but has not the multitude of drawbacks, in both safety and logistics, associated with live cells, are evident and paramount. As further discussed in Willis et al [116], the efficacy of MEx treatment has been reproducibly and robustly established in the laboratory, using diverse preclinical models of disease, but, for the industrialscale production of GMP-grade pharmaceuticals based on MEx to be used in clinical trials a number of technological and mechanistic issues must be resolved. These include the definition of a widely acceptable Potency Unit for MEx preparations, the standardization of the conditions for MSC culture and the protocols for MEx harvesting and storage. In addition, safety considerations also need to be addressed, although it may be expected that such concerns will be arguably milder than those relevant to live cell MSC treatment, as mutagenicity and oncogenicity concerns will be null.

The transition of MEx to the clinic will require the safety and production to be certified to a good manufacturing practice (GMP) quality. There is no current "gold" standard to isolate and purify exosomes in this still budding field. Commonly used methods such as ultracentrifugation often coprecipitate exosome preparations with nonexosomal-associated proteins/molecules, promot- 


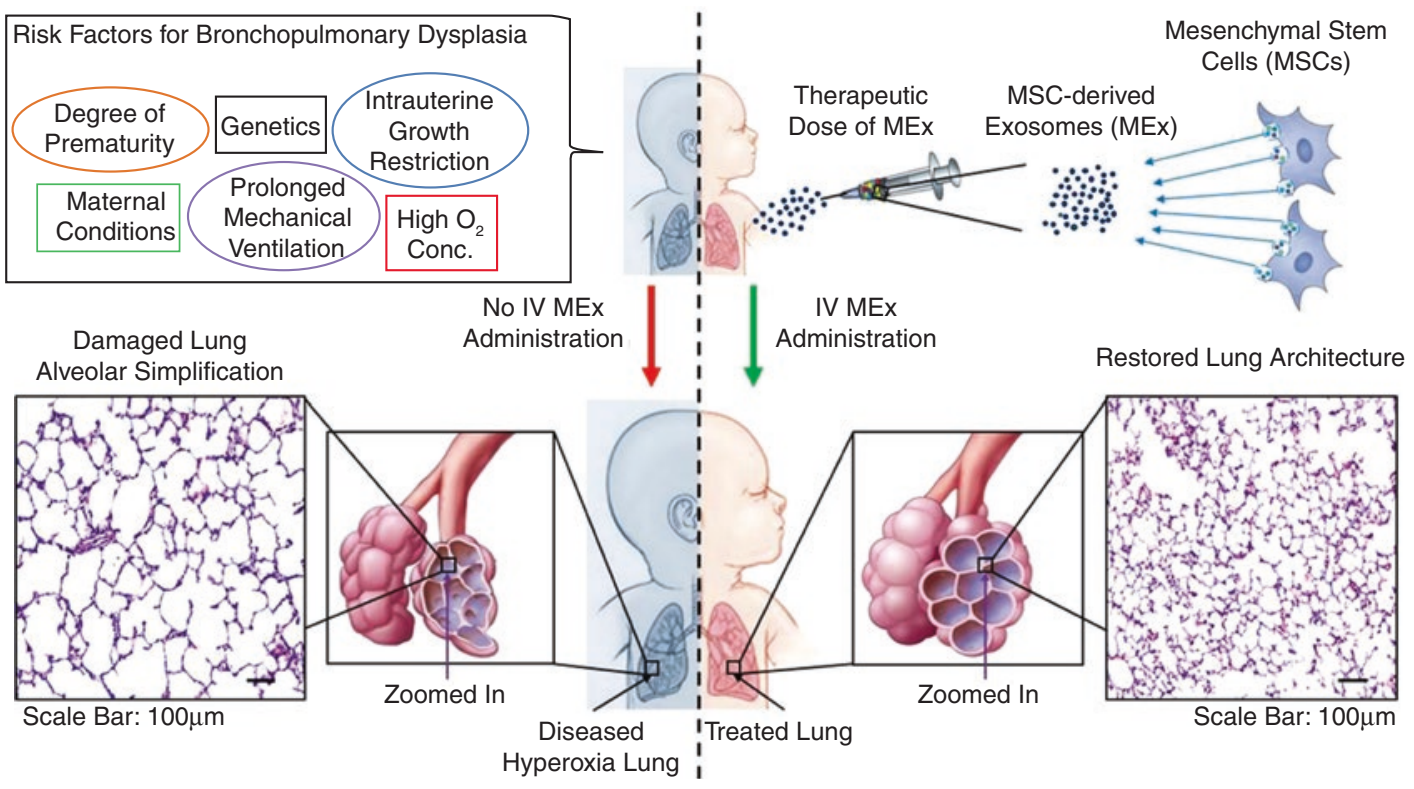

Fig. 8.3 Schematic summary for using mesenchymal stem cell-derived exosomes (MEx) for treating neonatal infants with bronchopulmonary dysplasia (BPD). Preterm infants with BPD have respiratory difficulties, characterized by lung growth arrest and emphysema-like features of lung disease (alveloar simplification), that can lead to pulmonary hypertension $(\mathrm{PH})$. Accumulating preclinical studies have demonstrated that the functional therapeutic

ing exosome aggregation which may alter its in vivo distribution and function $[123,146]$. For application to our preclinical models of lung disease we have isolated MEx from MSC CM by differential centrifugation and concentrated the product by tangential flow filtration (TFF) before MEx purification either by size-exclusion chromatography (SEC) [125] or through density flotation in an Iodixanol-based cushion gradient (Optiprep $^{\mathrm{TM}}$ ) [126]. Using the latter method, the MEx-containing fraction has a biochemical density of $1.18 \mathrm{~g} / \mathrm{ml}$ and contains a characteristically low protein to particle ratio, signifying efficient separation from nonvesicular components of the secretome. This methodology results in a product of high purity, but it is not suitable for manufacturing. MEx-based clinical trials will probably use products purified by alternative methods, amenable to large-scale production and GMP standards, most probably SEC. Without belittling the formidable challenges, we will face in our vector present in the mesenchymal stem cells (MSCs) secretome are extracellular vesicles, including exosomes (MEx), and MSC's therapeutic efficacy can be recapitulated by a cell-free MEx-based treatment. Here, we propose that intravenous delivery of MEx into preterm infants with BPD can restore lung architecutre and restore homeostasis in neonatal disease

efforts to translate MEx-based therapy from the laboratory bench to the NICU (Fig. 8.3), we are confident that we will witness the first clinical trials using MEx to treat BPD in the very near future.

Acknowledgments The authors express their appreciation to Dr. Angeles Fernandez-Gonzalez for critical reading of the final manuscript. Support was provided in part by the American Thoracic Society Research Grant (GRW); NIH Grant R01 HL055454 (SK); United Therapeutics Research Grant (SK \& SAM); and Charles H. Hood Foundation Major Grants Initiative (SK).

\section{References}

1. Luu T, Katz S, Leeson P, Thébaud B, Nuyt A-M. Preterm birth: risk factor for early-onset chronic diseases. CMAJ. 2016;188(10):736-40.

2. Polin RA, Carlo WA, Committee on F, Newborn, American Academy of Pediatrics. Surfactant replacement therapy for preterm and term neonates with respiratory distress. Pediatrics. 2014;133(1):156-63. https://doi.org/10.1542/peds.2013-3443. 
3. Willis GR, Kourembanas S, Mitsialis SA. Therapeutic applications of extracellular vesicles: perspectives from newborn medicine. In: Kuo WP, Jia S, editors. Extracellular vesicles: methods and protocols. New York, NY: Springer New York; 2017. p. 409-32. https://doi.org/10.1007/978-1-4939-7253-1_34.

4. Stoll BJ, Hansen NI, Bell EF, Walsh MC, Carlo WA, Shankaran S, Laptook AR, Sanchez PJ, Van Meurs KP, Wyckoff M, Das A, Hale EC, Ball MB, Newman NS, Schibler K, Poindexter BB, Kennedy KA, Cotten CM, Watterberg KL, D'Angio CT, DeMauro SB, Truog WE, Devaskar U, Higgins RD, Eunice Kennedy Shriver National Institute of Child H, Human Development Neonatal Research Network. Trends in care practices, morbidity, and mortality of extremely preterm neonates, 1993-2012. JAMA. 2015;314(10):1039-51. https://doi.org/10.1001/jama.2015.10244.

5. Doyle LW, Carse E, Adams AM, Ranganathan S, Opie G, JLY C, Victorian Infant Collaborative Study G. Ventilation in extremely preterm infants and respiratory function at 8 years. $\mathrm{N}$ Engl $\mathrm{J}$ Med. 2017;377(4):329-37. https://doi.org/10.1056/ NEJMoa1700827.

6. D'Angio C, Maniscalco W. Bronchopulmonary dysplasia in preterm infants: pathophysiology and management strategies. Paediatr Drugs. 2004;6(5):303-30.

7. Davidson LM, Berkelhamer SK. Bronchopulmonary dysplasia: chronic lung disease of infancy and longterm pulmonary outcomes. J Clin Med. 2017;6(4):120. https://doi.org/10.3390/jcm6010004.

8. Moschino L, Stocchero M, Filippone M, Carraro S, Baraldi E. Longitudinal assessment of lung function in survivors of Bronchopulmonary dysplasia from birth to adulthood. The Padova BPD study. Am J Respir Crit Care Med. 2018;198(1):134-7. https://doi. org/10.1164/rccm.201712-2599LE.

9. Al-Ghanem G, Shah P, Thomas S, Banfield L, El Helou S, Fusch C, Mukerji A. Bronchopulmonary dysplasia and pulmonary hypertension: a meta-analysis. $\mathrm{J}$ Perinatol. 2017;37(4):414-9. https://doi.org/10.1038/ jp.2016.250.

10. Berkelhamer SK, Mestan KK, Steinhorn R. An update on the diagnosis and management of bronchopulmonary dysplasia (BPD)-associated pulmonary hypertension. Semin Perinatol. 2018;42(7):432-43. https://doi. org/10.1053/j.semperi.2018.09.005.

11. Rysavy MA, Marlow N, Doyle LW, Tyson JE, Serenius F, Iams JD, Stoll BJ, Barrington KJ, Bell EF. Reporting outcomes of extremely preterm births. Pediatrics. 2016;138(3):1-7. https://doi.org/10.1542/ peds.2016-0689.

12. Kolios G, Moodley Y. Introduction to stem cells and regenerative medicine. Respiration. 2013;85(1):3-10. https://doi.org/10.1159/000345615.

13. Borghesi A, Cova C, Gazzolo D, Stronati M. Stem cell therapy for neonatal diseases associated with preterm birth. J Clin Neonatol. 2013;2(1):1-7. https://doi. org/10.4103/2249-4847.109230.

14. Thomson J, Itskovitz-Eldor J, Shapiro S, Waknitz M, Swiergiel J, Marshall V, Jones J. Embryonic stem cell lines derived from human blastocysts. Science. 1998;282(5391):1145-7.

15. Takahashi K, Yamanaka S. Induction of pluripotent stem cells from mouse embryonic and adult fibroblast cultures by defined factors. Cell. 2006;126(4):663-76. https://doi.org/10.1016/j.cell.2006.07.024.

16. Takahashi K, Tanabe K, Ohnuki M, Narita M, Ichisaka T, Tomoda K, Yamanaka S. Induction of pluripotent stem cells from adult human fibroblasts by defined factors. Cell. 2007;131(5):861-72. https://doi. org/10.1016/j.cell.2007.11.019.

17. Roszell B, Mondrinos M, Seaton A, Simons D, Koutzaki S, Fong G, Lelkes P, Finck C. Efficient derivation of alveolar type II cells from embryonic stem cells for in vivo application. Tissue Eng Part A. 2009;15(11):3351-65.

18. Huang SX, Islam MN, O'Neill J, Hu Z, Yang YG, Chen YW, Mumau M, Green MD, Vunjak-Novakovic G, Bhattacharya J, Snoeck HW. Efficient generation of lung and airway epithelial cells from human pluripotent stem cells. Nat Biotechnol. 2014;32(1):84-91. https://doi.org/10.1038/nbt.2754.

19. Jacob A, Morley M, Hawkins F, McCauley KB, Jean JC, Heins H, Na CL, Weaver TE, Vedaie M, Hurley K, Hinds A, Russo SJ, Kook S, Zacharias W, Ochs M, Traber K, Quinton LJ, Crane A, Davis BR, White FV, Wambach J, Whitsett JA, Cole FS, Morrisey EE, Guttentag SH, Beers MF, Kotton DN. Differentiation of human pluripotent stem cells into functional lung alveolar epithelial cells. Cell Stem Cell. 2017;21(4):472-88 . e410. https://doi.org/10.1016/j. stem.2017.08.014.

20. Shafa M, Ionescu LI, Vadivel A, Collins JJP, Xu L, Zhong S, Kang M, de Caen G, Daneshmand M, Shi J, Fu KZ, Qi A, Wang Y, Ellis J, Stanford WL, Thebaud B. Human induced pluripotent stem cellderived lung progenitor and alveolar epithelial cells attenuate hyperoxia-induced lung injury. Cytotherapy. 2018;20(1):108-25. https://doi.org/10.1016/j. jcyt.2017.09.003.

21. Lo B, Parham L. Ethical issues in stem cell research. Endocr Rev. 2009;30(3):204-13. https://doi. org/10.1210/er.2008-0031.

22. Gutierrez-Aranda I, Ramos-Mejia V, Bueno C, MunozLopez M, Real PJ, Macia A, Sanchez L, Ligero G, Garcia-Parez JL, Menendez P. Human induced pluripotent stem cells develop teratoma more efficiently and faster than human embryonic stem cells regardless the site of injection. Stem Cells. 2010;28(9):1568-70. https://doi.org/10.1002/stem.471.

23. Shi Y, Inoue H, Wu JC, Yamanaka S. Induced pluripotent stem cell technology: a decade of progress. Nat Rev Drug Discov. 2017;16(2):115-30. https://doi. org/10.1038/nrd.2016.245.

24. Barkauskas CE, Chung MI, Fioret B, Gao X, Katsura H, Hogan BL. Lung organoids: current uses and future promise. Development. 2017;144(6):986-97. https:// doi.org/10.1242/dev.140103.

25. Ghaedi M, Calle EA, Mendez JJ, Gard AL, Balestrini J, Booth A, Bove PF, Gui L, White ES, Niklason 
LE. Human iPS cell-derived alveolar epithelium repopulates lung extracellular matrix. J Clin Invest. 2013;123(11):4950-62. JCI68793.

26. Badylak SF, Taylor D, Uygun K. Whole-organ tissue engineering: decellularization and recellularization of three-dimensional matrix scaffolds. Annu Rev Biomed Eng. 2011;13:27-53. https://doi.org/10.1146/ annurev-bioeng-071910-124743.

27. Wagner DE, Bonenfant NR, Sokocevic D, DeSarno MJ, Borg ZD, Parsons CS, Brooks EM, Platz JJ, Khalpey ZI, Hoganson DM, Deng B, Lam YW, Oldinski RA, Ashikaga T, Weiss DJ. Three-dimensional scaffolds of acellular human and porcine lungs for high throughput studies of lung disease and regeneration. Biomaterials. 2014;35(9):2664-79. https://doi.org/10.1016/j. biomaterials.2013.11.078.

28. Titomanlio L, Kavelaars A, Dalous J, Mani S, El Ghouzzi V, Heijnen C, Baud O, Gressens P. Stem cell therapy for neonatal brain injury: perspectives and challenges. Ann Neurol. 2011;70(5):698-712. https:// doi.org/10.1002/ana.22518.

29. Bennet L, Tan S, Van den Heuij L, Derrick M, Groenendaal F, van Bel F, Juul S, Back SA, Northington F, Robertson NJ, Mallard C, Gunn AJ. Cell therapy for neonatal hypoxia-ischemia and cerebral palsy. Ann Neurol. 2012;71(5):589-600. https://doi.org/10.1002/ ana. 22670 .

30. Mitsialis SA, Kourembanas S. Stem cell-based therapies for the newborn lung and brain: possibilities and challenges. Semin Perinatol. 2016;40(3):138-51. https://doi.org/10.1053/j.semperi.2015.12.002.

31. Kang M, Thebaud B. Stem cell biology and regenerative medicine for neonatal lung diseases. Pediatr Res. 2018;83(1-2):291-7. https://doi.org/10.1038/ pr.2017.232.

32. Asahara T, Murohara T, Sullivan A, Silver M, van der Zee R, Li T, Witzenbichler B, Schatteman G, Isner J. Isolation of putative progenitor endothelial cells for angiogenesis. Science. 1997;275(5302):964-7.

33. Baker CD, Seedorf GJ, Wisniewski BL, Black CP, Ryan SL, Balasubramaniam V, Abman SH. Endothelial colony-forming cell conditioned media promote angiogenesis in vitro and prevent pulmonary hypertension in experimental bronchopulmonary dysplasia. Am J Physiol Lung Cell Mol Physiol. 2013;305(1):73-81. https://doi.org/10.1152/ajplung.00400.2012.

34. Alphonse RS, Vadivel A, Fung M, Shelley WC, Critser PJ, Ionescu L, O'Reilly M, Ohls RK, McConaghy S, Eaton F, Zhong S, Yoder M, Thebaud B. Existence, functional impairment, and lung repair potential of endothelial colony-forming cells in oxygeninduced arrested alveolar growth. Circulation. 2014;129(21):2144-57. https://doi.org/10.1161/ CIRCULATIONAHA.114.009124.

35. Firsova AB, Bird AD, Abebe D, Ng J, Mollard R, Cole TJ. Fresh noncultured endothelial progenitor cells improve neonatal lung hyperoxia-induced alveolar injury. Stem Cells Transl Med. 2017;6(12):2094-105. https://doi.org/10.1002/sctm.17-0093.
36. Ilancheran S, Michalska A, Peh G, Wallace EM, Pera M, Manuelpillai U. Stem cells derived from human fetal membranes display multilineage differentiation potential. Biol Reprod. 2007;77(3):577-88. https:// doi.org/10.1095/biolreprod.106.055244.

37. Vosdoganes P, Hodges RJ, Lim R, Westover AJ, Acharya RY, Wallace EM, Moss TJ. Human amnion epithelial cells as a treatment for inflammation-induced fetal lung injury in sheep. Am J Obstet Gynecol. 2011;205(156):26-33. https://doi.org/10.1016/j. ajog.2011.03.054.

38. Vosdoganes P, Wallace EM, Chan ST, Acharya R, Moss TJ, Lim R. Human amnion epithelial cells repair established lung injury. Cell Transplant. 2013;22(8):133749. https://doi.org/10.3727/096368912X657657.

39. Hodges RJ, Jenkin G, Hooper SB, Allison B, Lim R, Dickinson H, Miller SL, Vosdoganes P, Wallace EM. Human amnion epithelial cells reduce ventilation-induced preterm lung injury in fetal sheep. Am J Obstet Gynecol. 2012;206(448):8-15. https:// doi.org/10.1016/j.ajog.2012.02.038.

40. Melville JM, McDonald CA, Bischof RJ, Polglase GR, Lim R, Wallace EM, Jenkin G, Moss TJ. Human amnion epithelial cells modulate the inflammatory response to ventilation in preterm lambs. PLoS One. 2017;12(3):1-15. https://doi.org/10.1371/journal. pone.0173572.

41. Zhu D, Tan J, Maleken AS, Muljadi R, Chan ST, Lau SN, Elgass K, Leaw B, Mockler J, Chambers D, Leeman KT, Kim CF, Wallace EM, Lim R. Human amnion cells reverse acute and chronic pulmonary damage in experimental neonatal lung injury. Stem Cell Res Ther. 2017;8(257):1-24. https://doi. org/10.1186/s13287-017-0689-9.

42. Friedenstein A, Gorskaja J, Kulagina N. Fibroblast precursors in normal and irradiated mouse hematopoietic organs. Exp Hematol. 1976;4(5):267.

43. Zuk PA, Zhu M, Ashjian P, De Ugarte DA, Huang JI, Mizuno H, Alfonso ZC, Fraser JK, Benhaim P, Hedrick $\mathrm{MH}$. Human adipose tissue is a source of multipotent stem cells. Mol Biol Cell. 2002;13(12):4279-95. https://doi.org/10.1091/mbc.e02-02-0105.

44. Gronthos S, Mankani M, Brahim J, Robey P, Shi S. Postnatal human dental pulp stem cells (DPSCs) in vitro and in vivo. Proc Natl Acad Sci U S A. 2000;97(25):13625-30.

45. Wang HS, Hung SC, Peng ST, Huang CC, Wei HM, Guo YJ, Fu YS, Lai MC, Chen CC. Mesenchymal stem cells in the Wharton's jelly of the human umbilical cord. Stem Cells. 2004;22(7):1330-7. https://doi. org/10.1634/stemcells.2004-0013.

46. Dominici M, Le Blanc K, Mueller I, SlaperCortenbach I, Marini F, Krause D, Deans R, Keating A, Prockop D, Horwitz E. Minimal criteria for defining multipotent mesenchymal stromal cells. The International Society for Cellular Therapy position statement. Cytotherapy. 2006;8(4):315-7. https://doi. org/10.1080/14653240600855905.

47. Lindner U, Kramer J, Rohwedel J, Schlenke P. Mesenchymal stem or stromal cells: toward a 
better understanding of their biology? Transfus Med Hemother. 2010;37(2):75-83. https://doi. org/10.1159/000290897.

48. Phinney DG. Functional heterogeneity of mesenchymal stem cells: implications for cell therapy. J Cell Biochem. 2012;113(9):2806-12. https://doi. org/10.1002/jcb.24166.

49. Schaffler A, Buchler C. Concise review: adipose tissue-derived stromal cells-basic and clinical implications for novel cell-based therapies. Stem Cells. 2007;25(4):818-27. https://doi.org/10.1634/ stemcells.2006-0589.

50. Strioga M, Viswanathan S, Darinskas A, Slaby O, Michalek J. Same or not the same? Comparison of adipose tissue-derived versus bone marrow-derived mesenchymal stem and stromal cells. Stem Cells Dev. 2012;21(14):2724-52. https://doi.org/10.1089/ scd.2011.0722.

51. Davies JE, Walker JT, Keating A. Concise review: Wharton's Jelly: the rich, but enigmatic, source of mesenchymal stromal cells. Stem Cells Transl Med. 2017;6(7):1620-30. https://doi.org/10.1002/ sctm.16-0492.

52. Reis M, McDonald D, Nicholson L, Godthardt K, Knobel S, Dickinson AM, Filby A, Wang XN. Global phenotypic characterisation of human platelet lysate expanded MSCs by high-throughput flow cytometry. Sci Rep. 2018;8(3907):1-12. https://doi.org/10.1038/ s41598-018-22326-5.

53. McLeod CM, Mauck RL. On the origin and impact of mesenchymal stem cell heterogeneity: new insights and emerging tools for single cell analysis. Eur Cell Mater. 2017;34:217-31. https://doi.org/10.22203/ eCM.v034a14.

54. Weiss DJ. Concise review: current status of stem cells and regenerative medicine in lung biology and diseases. Stem Cells. 2014;32(1):16-25. https://doi. org/10.1002/stem.1506.

55. Foster WS, Suen CM, Stewart DJ. Regenerative cell and tissue-based therapies for pulmonary arterial hypertension. Can J Cardiol. 2014;30(11):1350-60. https://doi.org/10.1016/j.cjca.2014.08.022.

56. Kourembanas S. Stem cell-based therapy for newborn lung and brain injury: feasible, safe, and the next therapeutic breakthrough? J Pediatr. 2014;164(5):954-6. https://doi.org/10.1016/j.jpeds.2014.01.064.

57. Alvarez D, Levine M, Rojas M. Regenerative medicine in the treatment of idiopathic pulmonary fibrosis: current position. Stem Cells Cloning. 2015;8:61-5. https://doi.org/10.2147/SCCAA.S49801.

58. Suen CM, Zhai A, Lalu MM, Welsh C, Levac BM, Fergusson D, McIntyre L, Stewart DJ. Efficacy and safety of regenerative cell therapy for pulmonary arterial hypertension in animal models: a preclinical systematic review protocol. Syst Rev. 2016;5:89. https:// doi.org/10.1186/s13643-016-0265-x.

59. Broekman W, Khedoe P, Schepers K, Roelofs H, Stolk J, Hiemstra PS. Mesenchymal stromal cells: a novel therapy for the treatment of chronic obstructive pul- monary disease? Thorax. 2018;73(6):565-74. https:// doi.org/10.1136/thoraxjnl-2017-210672.

60. Ortiz LA, Gambelli F, McBride C, Gaupp D, Baddoo M, Kaminski N, Phinney DG. Mesenchymal stem cell engraftment in lung is enhanced in response to bleomycin exposure and ameliorates its fibrotic effects. Proc Natl Acad Sci U S A. 2003;100(14):8407-11. https://doi.org/10.1073/pnas.1432929100.

61. Rojas M, Xu J, Woods CR, Mora AL, Spears W, Roman J, Brigham KL. Bone marrow-derived mesenchymal stem cells in repair of the injured lung. Am J Respir Cell Mol Biol. 2005;33(2):145-52. https://doi. org/10.1165/rcmb.2004-03300C.

62. Moodley Y, Atienza D, Manuelpillai U, Samuel CS, Tchongue J, Ilancheran S, Boyd R, Trounson A. Human umbilical cord mesenchymal stem cells reduce fibrosis of bleomycin-induced lung injury. Am J Pathol. 2009;175(1):303-13. https://doi.org/10.2353/ ajpath.2009.080629.

63. Foskett AM, Bazhanov N, Ti X, Tiblow A, Bartosh TJ, Prockop DJ. Phase-directed therapy: TSG-6 targeted to early inflammation improves bleomycininjured lungs. Am J Physiol Lung Cell Mol Physiol. 2014;306(2):L120-31. https://doi.org/10.1152/ ajplung.00240.2013.

64. Srour N, Thebaud B. Mesenchymal stromal cells in animal Bleomycin pulmonary fibrosis models: a systematic review. Stem Cells Transl Med. 2015;4(12):1500-10. https://doi.org/10.5966/ sctm.2015-0121.

65. Zhao YD, Courtman DW, Deng Y, Kugathasan L, Zhang Q, Stewart DJ. Rescue of monocrotalineinduced pulmonary arterial hypertension using bone marrow-derived endothelial-like progenitor cells: efficacy of combined cell and eNOS gene therapy in established disease. Circ Res. 2005;96(4):442-50. https:// doi.org/10.1161/01.RES.0000157672.70560.7b.

66. Kanki-Horimoto S, Horimoto H, Mieno S, Kishida K, Watanabe F, Furuya E, Katsumata T. Implantation of mesenchymal stem cells overexpressing endothelial nitric oxide synthase improves right ventricular impairments caused by pulmonary hypertension. Circulation. 2006;114(1 Suppl):I181-5. https://doi. org/10.1161/CIRCULATIONAHA.105.001487.

67. Spees JL, Whitney MJ, Sullivan DE, Lasky JA, Laboy M, Ylostalo J, Prockop DJ. Bone marrow progenitor cells contribute to repair and remodeling of the lung and heart in a rat model of progressive pulmonary hypertension. FASEB J. 2008;22(4):1226-36. https:// doi.org/10.1096/fj.07-8076com.

68. Baber SR, Deng W, Master RG, Bunnell BA, Taylor BK, Murthy SN, Hyman AL, Kadowitz PJ. Intratracheal mesenchymal stem cell administration attenuates monocrotaline-induced pulmonary hypertension and endothelial dysfunction. Am J Physiol Heart Circ Physiol. 2007;292(2):1120-8. https://doi.org/10.1152/ajpheart.00173.2006.

69. Umar S, de Visser YP, Steendijk P, Schutte CI, el Laghmani H, Wagenaar GT, Bax WH, Mantikou E, 
Pijnappels DA, Atsma DE, Schalij MJ, van der Wall EE, van der Laarse A. Allogenic stem cell therapy improves right ventricular function by improving lung pathology in rats with pulmonary hypertension. Am J Physiol Heart Circ Physiol. 2009;297(5):1606-16. https://doi.org/10.1152/ajpheart.00590.2009.

70. Liang OD, Mitsialis SA, Chang MS, Vergadi E, Lee C, Aslam M, Fernandez-Gonzalez A, Liu X, Baveja R, Kourembanas S. Mesenchymal stromal cells expressing heme oxygenase-1 reverse pulmonary hypertension. Stem Cells. 2011;29(1):99-107. https://doi. org/10.1002/stem.548.

71. Aslam M, Baveja R, Liang OD, Fernandez-Gonzalez A, Lee C, Mitsialis SA, Kourembanas S. Bone marrow stromal cells attenuate lung injury in a murine model of neonatal chronic lung disease. Am J Respir Crit Care Med. 2009;180(11):1122-30. https://doi. org/10.1164/rccm.200902-0242OC.

72. van Haaften T, Byrne R, Bonnet S, Rochefort GY, Akabutu J, Bouchentouf M, Rey-Parra GJ, Galipeau J, Haromy A, Eaton F, Chen M, Hashimoto K, Abley D, Korbutt G, Archer SL, Thebaud B. Airway delivery of mesenchymal stem cells prevents arrested alveolar growth in neonatal lung injury in rats. Am J Respir Crit Care Med. 2009;180(11):1131-42. https://doi. org/10.1164/rccm.200902-0179OC.

73. Chang YS, Choi SJ, Ahn SY, Sung DK, Sung SI, Yoo HS, Oh WI, Park WS. Timing of umbilical cord blood derived mesenchymal stem cells transplantation determines therapeutic efficacy in the neonatal hyperoxic lung injury. PLoS One. 2013;8(1):1-11. https://doi. org/10.1371/journal.pone.0052419.

74. Pierro M, Ionescu L, Montemurro T, Vadivel A, Weissmann G, Oudit G, Emery D, Bodiga S, Eaton F, Peault B, Mosca F, Lazzari L, Thebaud B. Short-term, long-term and paracrine effect of human umbilical cord-derived stem cells in lung injury prevention and repair in experimental bronchopulmonary dysplasia. Thorax. 2013;68(5):475-84. https://doi.org/10.1136/ thoraxjnl-2012-202323.

75. Vergadi E, Chang MS, Lee C, Liang OD, Liu X, Fernandez-Gonzalez A, Mitsialis SA, Kourembanas S. Early macrophage recruitment and alternative activation are critical for the later development of hypoxiainduced pulmonary hypertension. Circulation. 2011;123(18):1986-95. https://doi.org/10.1161/ CIRCULATIONAHA.110.978627.

76. Kotton DN, Ma BY, Cardoso WV, Sanderson EA, Summer RS, Williams MC, Fine A. Bone marrowderived cells as progenitors of lung alveolar epithelium. Development. 2001;128(24):5181-8.

77. Kotton DN, Fine A. Derivation of lung epithelium from bone marrow cells. Cytotherapy. 2003;5(2):16973. https://doi.org/10.1080/14653240310001073.

78. Aliotta JM, Passero M, Meharg J, Klinger J, Dooner MS, Pimentel J, Quesenberry PJ. Stem cells and pulmonary metamorphosis: new concepts in repair and regeneration. J Cell Physiol. 2005;204(3):725-41. https://doi.org/10.1002/jcp.20318.

79. Hansmann G, Fernandez-Gonzalez A, Aslam M, Vitali SH, Martin T, Mitsialis SA, Kourembanas
S. Mesenchymal stem cell-mediated reversal of bronchopulmonary dysplasia and associated pulmonary hypertension. Pulm Circ. 2012;2(2):170-81. https:// doi.org/10.4103/2045-8932.97603.

80. Abman SH, Matthay MA. Mesenchymal stem cells for the prevention of bronchopulmonary dysplasia: delivering the secretome. Am J Respir Crit Care Med. 2009;180(11):1039-41. https://doi.org/10.1164/ rccm.200909-1330ED.

81. Lee JW, Fang X, Krasnodembskaya A, Howard JP, Matthay MA. Concise review: Mesenchymal stem cells for acute lung injury: role of paracrine soluble factors. Stem Cells. 2011;29(6):913-9. https://doi. org/10.1002/stem.643.

82. Timmers L, Lim SK, Arslan F, Armstrong JS, Hoefer IE, Doevendans PA, Piek JJ, El Oakley RM, Choo A, Lee CN, Pasterkamp G, de Kleijn DP. Reduction of myocardial infarct size by human mesenchymal stem cell conditioned medium. Stem Cell Res. 2007;1(2):129-37. https://doi.org/10.1016/j. scr.2008.02.002.

83. Patel KM, Crisostomo P, Lahm T, Markel T, Herring C, Wang M, Meldrum KK, Lillemoe KD, Meldrum DR. Mesenchymal stem cells attenuate hypoxic pulmonary vasoconstriction by a paracrine mechanism. J Surg Res. 2007;143(2):281-5. https://doi. org/10.1016/j.jss.2006.11.006.

84. Curley GF, Hayes M, Ansari B, Shaw G, Ryan A, Barry F, O'Brien T, O'Toole D, Laffey JG. Mesenchymal stem cells enhance recovery and repair following ventilator-induced lung injury in the rat. Thorax. 2012;67(6):496-501. https://doi.org/10.1136/ thoraxjnl-2011-201059.

85. Augustine S, Avey MT, Harrison B, Locke T, Ghannad M, Moher D, Thebaud B. Mesenchymal stromal cell therapy in bronchopulmonary dysplasia: systematic review and meta-analysis of preclinical studies. Stem Cells Transl Med. 2017;6(12):2079-93. https://doi. org/10.1002/sctm.17-0126.

86. Iyer SS, Rojas M. Anti-inflammatory effects of mesenchymal stem cells: novel concept for future therapies. Expert Opin Biol Ther. 2008;8(5):569-81. https://doi. org/10.1517/14712598.8.5.569.

87. Prockop DJ. Concise review: two negative feedback loops place mesenchymal stem/stromal cells at the center of early regulators of inflammation. Stem Cells. 2013;31(10):2042-6. https://doi.org/10.1002/ stem. 1400 .

88. Lathrop MJ, Brooks EM, Bonenfant NR, Sokocevic D, Borg ZD, Goodwin M, Loi R, Cruz F, Dunaway CW, Steele C, Weiss DJ. Mesenchymal stromal cells mediate Aspergillus hyphal extract-induced allergic airway inflammation by inhibition of the Th17 signaling pathway. Stem Cells Transl Med. 2014;3(2):194-205. https://doi.org/10.5966/ sctm.2013-0061.

89. Meirelles Lda S, Fontes AM, Covas DT, Caplan AI. Mechanisms involved in the therapeutic properties of mesenchymal stem cells. Cytokine Growth Factor Rev. 2009;20(5-6):419-27. https://doi.org/10.1016/j. cytogfr.2009.10.002. 
90. Ortiz LA, Dutreil M, Fattman C, Pandey AC, Torres G, Go K, Phinney DG. Interleukin 1 receptor antagonist mediates the antiinflammatory and antifibrotic effect of mesenchymal stem cells during lung injury. Proc Natl Acad Sci U S A. 2007;104(26):11002-7. https:// doi.org/10.1073/pnas.0704421104.

91. Lee RH, Yu JM, Foskett AM, Peltier G, Reneau JC, Bazhanov N, Oh JY, Prockop DJ. TSG-6 as a biomarker to predict efficacy of human mesenchymal stem/progenitor cells (hMSCs) in modulating sterile inflammation in vivo. Proc Natl Acad Sci U S A. 2014;111(47):16766-71. https://doi.org/10.1073/ pnas. 1416121111.

92. Colombo M, Raposo G, Thery C. Biogenesis, secretion, and intercellular interactions of exosomes and other extracellular vesicles. Annu Rev Cell Dev Biol. 2014;30:255-89. https://doi.org/10.1146/ annurev-cellbio-101512-122326.

93. Raposo G, Stoorvogel W. Extracellular vesicles: exosomes, microvesicles, and friends. J Cell Biol. 2013;200(4):373-83. jcb.201211138.

94. Gould SJ, Raposo G. As we wait: coping with an imperfect nomenclature for extracellular vesicles. J Extracell Vesicles. 2013;2(20389):1-3. https://doi. org/10.3402/jev.v2i0.20389.

95. Lotvall J, Hill AF, Hochberg F, Buzas EI, Di Vizio D, Gardiner C, Gho YS, Kurochkin IV, Mathivanan S, Quesenberry P, Sahoo S, Tahara H, Wauben MH, Witwer KW, Thery C. Minimal experimental requirements for definition of extracellular vesicles and their functions: a position statement from the International Society for Extracellular Vesicles. J Extracell Vesicles. 2014;3(26913):1-6. https://doi.org/10.3402/jev.v3.26913.

96. Witwer KW, Soekmadji C, Hill AF, Wauben MH, Buzas EI, Di Vizio D, Falcon-Perez JM, Gardiner C, Hochberg F, Kurochkin IV, Lotvall J, Mathivanan S, Nieuwland R, Sahoo S, Tahara H, Torrecilhas AC, Weaver AM, Yin H, Zheng L, Gho YS, Quesenberry P, Thery C. Updating the MISEV minimal requirements for extracellular vesicle studies: building bridges to reproducibility. J Extracell Vesicles. 2017;6(1):1-8. https://doi.org/10.1080/20013078.2017.1396823.

97. Zhang H, Freitas D, Kim HS, Fabijanic K, Li Z, Chen H, Mark MT, Molina H, Martin AB, Bojmar L, Fang J, Rampersaud S, Hoshino A, Matei I, Kenific CM, Nakajima M, Mutvei AP, Sansone P, Buehring W, Wang H, Jimenez JP, Cohen-Gould L, Paknejad N, Brendel M, Manova-Todorova K, Magalhaes A, Ferreira JA, Osorio H, Silva AM, Massey A, CubillosRuiz JR, Galletti G, Giannakakou P, Cuervo AM, Blenis J, Schwartz R, Brady MS, Peinado H, Bromberg J, Matsui H, Reis CA, Lyden D. Identification of distinct nanoparticles and subsets of extracellular vesicles by asymmetric flow field-flow fractionation. Nat Cell Biol. 2018;20(3):332-43. https://doi.org/10.1038/ s41556-018-0040-4.

98. Gould G, Lippincott-Schwartz J. New roles for endosomes: from vesicular carriers to multi-purpose platforms. Nat Rev Mol Cell Biol. 2009;10(4):287-92.
99. Henne WM, Buchkovich NJ, Emr SD. The ESCRT pathway. Dev Cell. 2011;21(1):77-91. https://doi. org/10.1016/j.devcel.2011.05.015.

100. Stenmark H. Rab GTPases as coordinators of vesicle traffic. Nat Rev Mol Cell Biol. 2009;10(8):513-25. https://doi.org/10.1038/nrm2728.

101. Stenmark H, Olkkonen VM. The Rab GTPase family. Genome Biol. 2001;2(5):1-7.

102. Jahn R, Scheller RH. SNAREs-engines for membrane fusion. Nat Rev Mol Cell Biol. 2006;7(9):63143. https://doi.org/10.1038/nrm2002.

103. Rao SK, Huynh C, Proux-Gillardeaux V, Galli T, Andrews NW. Identification of SNAREs involved in synaptotagmin VII-regulated lysosomal exocytosis. J Biol Chem. 2004;279(19):20471-9. https://doi. org/10.1074/jbc.M400798200.

104. Chaineau M, Danglot L, Galli T. Multiple roles of the vesicular-SNARE TI-VAMP in post-Golgi and endosomal trafficking. FEBS Lett. 2009;583(23):381726. https://doi.org/10.1016/j.febslet.2009.10.026.

105. Mathivanan S, Simpson RJ. ExoCarta: a compendium of exosomal proteins and RNA. Proteomics. 2009;9(21):4997-5000. https://doi.org/10.1002/ pmic. 200900351.

106. Kalra H, Simpson RJ, Ji H, Aikawa E, Altevogt P, Askenase P, Bond VC, Borras FE, Breakefield X, Budnik V, Buzas E, Camussi G, Clayton A, Cocucci E, Falcon-Perez JM, Gabrielsson S, Gho YS, Gupta D, Harsha HC, Hendrix A, Hill AF, Inal JM, Jenster G, Kramer-Albers EM, Lim SK, Llorente A, Lotvall J, Marcilla A, Mincheva-Nilsson L, Nazarenko I, Nieuwland R, Nolte-'t Hoen EN, Pandey A, Patel T, Piper MG, Pluchino S, Prasad TS, Rajendran L, Raposo G, Record M, Reid GE, Sanchez-Madrid F, Schiffelers RM, Siljander P, Stensballe A, Stoorvogel W, Taylor D, Thery C, Valadi H, van Balkom BW, Vazquez J, Vidal M, Wauben MH, Yanez-Mo M, Zoeller M, Mathivanan S. Vesiclepedia: a compendium for extracellular vesicles with continuous community annotation. PLoS Biol. 2012;10(12):1-5. https://doi.org/10.1371/journal.pbio.1001450.

107. Kim DK, Lee J, Kim SR, Choi DS, Yoon YJ, Kim JH, Go G, Nhung D, Hong K, Jang SC, Kim SH, Park KS, Kim OY, Park HT, Seo JH, Aikawa E, Baj-Krzyworzeka M, van Balkom BW, Belting M, Blanc L, Bond V, Bongiovanni A, Borras FE, Buee L, Buzas EI, Cheng L, Clayton A, Cocucci E, Dela Cruz CS, Desiderio DM, Di Vizio D, Ekstrom K, Falcon-Perez JM, Gardiner C, Giebel B, Greening DW, Gross JC, Gupta D, Hendrix A, Hill AF, Hill MM, Nolte-'t Hoen E, Hwang DW, Inal J, Jagannadham MV, Jayachandran M, Jee YK, Jorgensen M, Kim KP, Kim YK, Kislinger T, Lasser C, Lee DS, Lee H, van Leeuwen J, Lener T, Liu ML, Lotvall J, Marcilla A, Mathivanan S, Moller A, Morhayim J, Mullier F, Nazarenko I, Nieuwland R, Nunes DN, Pang K, Park J, Patel T, Pocsfalvi G, Del Portillo H, Putz U, Ramirez MI, Rodrigues ML, Roh TY, Royo F, Sahoo S, Schiffelers R, Sharma S, Siljander P, Simpson RJ, Soekmadji C, Stahl 
P, Stensballe A, Stepien E, Tahara H, Trummer A, Valadi H, Vella LJ, Wai SN, Witwer K, Yanez-Mo M, Youn H, Zeidler R, Gho YS. EVpedia: a community web portal for extracellular vesicles research. Bioinformatics. 2015;31(6):933-9. https://doi. org/10.1093/bioinformatics/btu741.

108. Li S, Li Y, Chen B, Zhao J, Yu S, Tang Y, Zheng Q, Li Y, Wang P, He X, Huang S. exoRBase: a database of circRNA, lncRNA and mRNA in human blood exosomes. Nucleic Acids Res. 2018;46(1):106-12. https://doi.org/10.1093/nar/gkx891.

109. Connolly KD, Guschina IA, Yeung V, Clayton A, Draman MS, Von Ruhland C, Ludgate M, James PE, Rees DA. Characterisation of adipocyte-derived extracellular vesicles released pre- and postadipogenesis. J Extracell Vesicles. 2015;4(29159):110. https://doi.org/10.3402/jev.v4.29159.

110. Hoshino A, Costa-Silva B, Shen TL, Rodrigues G, Hashimoto A, Tesic Mark M, Molina H, Kohsaka S, Di Giannatale A, Ceder S, Singh S, Williams C, Soplop N, Uryu K, Pharmer L, King T, Bojmar L, Davies AE, Ararso Y, Zhang T, Zhang H, Hernandez J, Weiss JM, Dumont-Cole VD, Kramer K, Wexler LH, Narendran A, Schwartz GK, Healey JH, Sandstrom P, Labori KJ, Kure EH, Grandgenett PM, Hollingsworth MA, de Sousa M, Kaur S, Jain M, Mallya K, Batra SK, Jarnagin WR, Brady MS, Fodstad O, Muller V, Pantel K, Minn AJ, Bissell MJ, Garcia BA, Kang Y, Rajasekhar VK, Ghajar CM, Matei I, Peinado H, Bromberg J, Lyden D. Tumour exosome integrins determine organotropic metastasis. Nature. 2015;527(7578):329-35. https://doi. org/10.1038/nature 15756 .

111. Mulcahy LA, Pink RC, Carter DR. Routes and mechanisms of extracellular vesicle uptake. J Extracell Vesicles. 2014;3(24641):1-14. https://doi. org/10.3402/jev.v3.24641.

112. Sdrimas K, Kourembanas S. MSC microvesicles for the treatment of lung disease: a new paradigm for cell-free therapy. Antioxid Redox Signal. 2014;21(13):1905-15. https://doi.org/10.1089/ ars.2013.5784.

113. Webber J, Yeung V, Clayton A. Extracellular vesicles as modulators of the cancer microenvironment. Semin Cell Dev Biol. 2015;40:27-34. https://doi. org/10.1016/j.semcdb.2015.01.013.

114. Phinney DG, Pittenger MF. Concise review: MSCderived exosomes for cell-free therapy. Stem Cells. 2017;35(4):851-8. https://doi.org/10.1002/ stem. 2575.

115. Shephard AP, Yeung V, Clayton A, Webber JP. Prostate cancer exosomes as modulators of the tumor microenvironment. J Cancer Metastasis Treat. 2017;3(12):288-301. https://doi. org/10.20517/2394-4722.2017.32.

116. Willis GR, Kourembanas S, Mitsialis SA. Toward exosome-based therapeutics: isolation, heterogeneity, and fit-for-purpose potency. Front Cardiovasc Med. 2017;4(63):1-13. https://doi.org/10.3389/ fcvm.2017.00063.
117. Valadi H, Ekstrom K, Bossios A, Sjostrand M, Lee JJ, Lotvall JO. Exosome-mediated transfer of mRNAs and microRNAs is a novel mechanism of genetic exchange between cells. Nat Cell Biol. 2007;9(6):654-9. https://doi.org/10.1038/ncb1596.

118. Pegtel DM, Cosmopoulos K, Thorley-Lawson DA, van Eijndhoven MA, Hopmans ES, Lindenberg JL, de Gruijl TD, Wurdinger T, Middeldorp JM. Functional delivery of viral miRNAs via exosomes. Proc Natl Acad Sci U S A. 2010;107(14):6328-33. https://doi. org/10.1073/pnas.0914843107.

119. Kosaka N, Iguchi H, Yoshioka Y, Takeshita F, Matsuki Y, Ochiya T. Secretory mechanisms and intercellular transfer of microRNAs in living cells. J Biol Chem. 2010;285(23):17442-52. https://doi. org/10.1074/jbc.M110.107821.

120. Xiao C, Wang K, Xu Y, Hu H, Zhang N, Wang Y, Zhong Z, Zhao J, Li Q, Zhu D, Ke C, Zhong S, Wu X, Yu H, Zhu W, Chen J, Zhang J, Wang J, Hu X. Transplanted mesenchymal stem cells reduce autophagic flux in infarcted hearts via the exosomal transfer of mir-125b. Circ Res. 2018;123(5):564-78. https://doi.org/10.1161/ CIRCRESAHA.118.312758.

121. Au Yeung CL, Co NN, Tsuruga T, Yeung TL, Kwan SY, Leung CS, Li Y, Lu ES, Kwan K, Wong KK, Schmandt R, Lu KH, Mok SC. Exosomal transfer of stroma-derived miR21 confers paclitaxel resistance in ovarian cancer cells through targeting APAF1. Nat Commun. 2016;7(11150):1-14. https://doi. org/10.1038/ncomms11150.

122. Li L, Li C, Wang S, Wang Z, Jiang J, Wang W, Li X, Chen J, Liu K, Li C, Zhu G. Exosomes derived from hypoxic oral squamous cell carcinoma cells deliver miR-21 to normoxic cells to elicit a prometastatic phenotype. Cancer Res. 2016;76(7):1770-80. https://doi.org/10.1158/0008-5472.CAN-15-1625.

123. Willms E, Johansson HJ, Mager I, Lee Y, Blomberg KE, Sadik M, Alaarg A, Smith CI, Lehtio J, El Andaloussi S, Wood MJ, Vader P. Cells release subpopulations of exosomes with distinct molecular and biological properties. Sci Rep. 2016;6(22519):1-12. https://doi.org/10.1038/srep22519.

124. Yeung V, Webber JP, Dunlop EA, Morgan H, Hutton J, Gurney M, Jones E, Falcon-Perez J, Tabi Z, Errington R, Clayton A. Rab35-dependent extracellular nanovesicles are required for induction of tumour supporting stroma. Nanoscale. 2018;10(18):8547-59. https://doi.org/10.1039/ c8nr02417k.

125. Lee C, Mitsialis SA, Aslam M, Vitali SH, Vergadi E, Konstantinou G, Sdrimas K, Fernandez-Gonzalez A, Kourembanas S. Exosomes mediate the cytoprotective action of mesenchymal stromal cells on hypoxia-induced pulmonary hypertension. Circulation. 2012;126(22):2601-11. https://doi. org/10.1161/CIRCULATIONAHA.112.114173.

126. Willis GR, Fernandez-Gonzalez A, Anastas J, Vitali SH, Liu X, Ericsson M, Kwong A, Mitsialis SA, Kourembanas S. Mesenchymal stromal cell exo- 
somes ameliorate experimental bronchopulmonary dysplasia and restore lung function through macrophage immunomodulation. Am J Respir Crit Care Med. 2018;197(1):104-16. https://doi.org/10.1164/ rccm.201705-0925OC.

127. Kourembanas S. Exosomes: vehicles of intercellular signaling, biomarkers, and vectors of cell therapy. Annu Rev Physiol. 2015;77:13-27. https://doi. org/10.1146/annurev-physiol-021014-071641.

128. Willis GR, Mitsialis SA, Kourembanas S. "Good things come in small packages": application of exosome-based therapeutics in neonatal lung injury. Pediatr Res. 2017;83(1-2):298-307. https://doi. org/10.1038/pr.2017.256.

129. Willis GR, Fernandez-Gonzalez A, Reis M, Mitsialis SA, Kourembanas S. Macrophage immunomodulation: the gatekeeper for mesenchymal stem cell derived-exosomes in pulmonary arterial hypertension? Int J Mol Sci. 2018;19(2534):1-19. https://doi. org/10.3390/ijms19092534.

130. Bruno S, Grange C, Deregibus MC, Calogero RA, Saviozzi S, Collino F, Morando L, Busca A, Falda M, Bussolati B, Tetta C, Camussi G. Mesenchymal stem cell-derived microvesicles protect against acute tubular injury. J Am Soc Nephrol. 2009;20(5):105367. https://doi.org/10.1681/ASN.2008070798.

131. Lai RC, Arslan F, Lee MM, Sze NSK, Choo A, Chen TS, Salto-Tellez M, Timmers L, Lee CN, El Oakley RM, Pasterkamp G, de Kleijn DPV, Lim SK. Exosome secreted by MSC reduces myocardial ischemia/reperfusion injury. Stem Cell Res. 2010;4(3):214-22. https://doi.org/10.1016/j. scr.2009.12.003.

132. Cruz FF, Borg ZD, Goodwin M, Sokocevic D, Wagner DE, Coffey A, Antunes M, Robinson KL, Mitsialis SA, Kourembanas S, Thane K, Hoffman AM, McKenna DH, Rocco PR, Weiss DJ. Systemic administration of human bone marrow-derived mesenchymal stromal cell extracellular vesicles ameliorates aspergillus hyphal extract-induced allergic airway inflammation in immunocompetent mice. Stem Cells Transl Med. 2015;4(11):1302-16. https://doi.org/10.5966/sctm.2014-0280.

133. Chen JY, An R, Liu ZJ, Wang JJ, Chen SZ, Hong MM, Liu JH, Xiao MY, Chen YF. Therapeutic effects of mesenchymal stem cell-derived microvesicles on pulmonary arterial hypertension in rats. Acta Pharmacol Sin. 2014;35(9):1121-8. https://doi. org/10.1038/aps.2014.61.

134. Aliotta JM, Pereira M, Wen S, Dooner MS, Del Tatto M, Papa E, Goldberg LR, Baird GL, Ventetuolo CE, Quesenberry PJ, Klinger JR. Exosomes induce and reverse monocrotaline-induced pulmonary hypertension in mice. Cardiovasc Res. 2016;110(3):319-30. https://doi.org/10.1093/cvr/cvw054.

135. Chaubey S, Thueson S, Ponnalagu D, Alam MA, Gheorghe CP, Aghai Z, Singh H, Bhandari V. Early gestational mesenchymal stem cell secretome attenuates experimental bronchopulmonary dysplasia in part via exosome-associated factor TSG-6.
Stem Cell Res Ther. 2018;9(173):1-26. https://doi. org/10.1186/s13287-018-0903-4.

136. Porzionato A, Zaramella P, Dedja A, Guidolin D, Van Wemmel K, Macchi V, Jurga M, Perilongo G, De Caro R, Baraldi E, Muraca M. Intratracheal administration of clinical-grade mesenchymal stem cellderived extracellular vesicles reduces lung injury in a rat model of bronchopulmonary dysplasia. Am J Physiol Lung Cell Mol Physiol. 2019;316(1):L6L19. https://doi.org/10.1152/ajplung.00109.2018.

137. Liu KD, Wilson JG, Zhuo H, Caballero L, McMillan ML, Fang X, Cosgrove K, Calfee CS, Lee JW, Kangelaris KN, Gotts JE, Rogers AJ, Levitt JE, Wiener-Kronish JP, Delucchi KL, Leavitt AD, McKenna DH, Thompson BT, Matthay MA. Design and implementation of the START (STem cells for ARDS treatment) trial, a phase $1 / 2$ trial of human mesenchymal stem/stromal cells for the treatment of moderate-severe acute respiratory distress syndrome. Ann Intensive Care. 2014;4:22. https://doi. org/10.1186/s13613-014-0022-z.

138. Wilson JG, Liu KD, Zhuo H, Caballero L, McMillan M, Fang X, Cosgrove K, Vojnik R, Calfee CS, Lee JW, Rogers AJ, Levitt J, Wiener-Kronish J, Bajwa EK, Leavitt A, McKenna D, Thompson BT, Matthay MA. Mesenchymal stem (stromal) cells for treatment of ARDS: a phase 1 clinical trial. Lancet Respir Med. 2015;3(1):24-32. https://doi.org/10.1016/ S2213-2600(14)70291-7.

139. Matthay MA, Calfee CS, Zhuo H, Thompson BT, Wilson JG, Levitt JE, Rogers AJ, Gotts JE, WienerKronish JP, Bajwa EK, Donahoe MP, McVerry BJ, Ortiz LA, Exline M, Christman JW, Abbott J, Delucchi KL, Caballero L, McMillan M, McKenna $\mathrm{DH}$, Liu KD. Treatment with allogeneic mesenchymal stromal cells for moderate to severe acute respiratory distress syndrome (START study): a randomised phase $2 \mathrm{a}$ safety trial. Lancet Respir Med. 2019;7(2):154-62. https://doi.org/10.1016/ S2213-2600(18)30418-1.

140. Armitage J, Tan DBA, Troedson R, Young P, Lam KV, Shaw K, Sturm M, Weiss DJ, Moodley YP. Mesenchymal stromal cell infusion modulates systemic immunological responses in stable COPD patients: a phase I pilot study. Eur Respir J. 2018;51(3):1702369. https://doi. org/10.1183/13993003.02369-2017.

141. Chang YS, Ahn SY, Yoo HS, Sung SI, Choi SJ, Oh WI, Park WS. Mesenchymal stem cells for bronchopulmonary dysplasia: phase 1 dose-escalation clinical trial. J Pediatr. 2014;164(5):966-72. https://doi. org/10.1016/j.jpeds.2013.12.011.

142. Schulz KF, Altman DG, Moher D. CONSORT 2010 statement: updated guidelines for reporting parallel group randomised trials. J Pharmacol Pharmacother. 2010;1(2):100-7. https://doi. org/10.4103/0976-500x.72352.

143. Ahn SY, Chang YS, Kim JH, Sung SI, Park WS. Two-year follow-up outcomes of premature infants enrolled in the phase I trial of mesenchymal 
stem cells transplantation for bronchopulmonary dysplasia. J Pediatr. 2017;185:49-54. https://doi. org/10.1016/j.jpeds.2017.02.061.

144. Powell SB, Silvestri JM. Safety of intratracheal administration of human umbilical cord blood derived mesenchymal stromal cells in extremely low birth weight preterm infants. J Pediatr. 2019;210:209-13. https://doi.org/10.1016/j.jpeds.2019.02.029.

145. Loisel F, Provost B, Haddad F, Guihaire J, Amsallem M, Vrtovec B, Fadel E, Uzan G, Mercier O. Stem cell therapy targeting the right ventricle in pulmonary arterial hypertension: is it a potential avenue of therapy? Pulm Circ. 2018;8(2):1-17. https://doi. org/10.1177/2045893218755979.

146. Van Deun J, Mestdagh P, Sormunen R, Cocquyt V, Vermaelen K, Vandesompele J, Bracke M, De Wever $\mathrm{O}$, Hendrix A. The impact of disparate isolation methods for extracellular vesicles on downstream RNA profiling. J Extracell Vesicles. 2014;3(24858):1-14. https://doi.org/10.3402/jev.v3.24858

147. Ostrowski M, Carmo NB, Krumeich S, Fanget I, Raposo G, Savina A, Moita CF, Schauer K, Hume AN, Freitas RP, Goud B, Benaroch P, Hacohen N, Fukuda M, Desnos C, Seabra MC, Darchen F, Amigorena S, Moita LF, Thery C. Rab27a and Rab27b control different steps of the exosome secretion pathway. Nat Cell Biol. 2010;12(1):19-30. https://doi.org/10.1038/ncb2000.

148. Bobrie A, Krumeich S, Reyal F, Recchi C, Moita LF, Seabra MC, Ostrowski M, Thery C. Rab27a supports exosome-dependent and -independent mechanisms that modify the tumor microenvironment and can promote tumor progression. Cancer Res. 2012;72(19):4920-30. https://doi.org/10.1158/00085472.CAN-12-0925. 